\title{
Observing and modelling phytoplankton community structure in the North Sea
}

\author{
David A. Ford ${ }^{1}$, Johan van der Molen ${ }^{2,3}$, Kieran Hyder ${ }^{2}$, John Bacon ${ }^{2}$, Rosa Barciela ${ }^{1}$, Veronique Creach ${ }^{2}$, \\ Robert McEwan ${ }^{1}$, Piet Ruardij ${ }^{3}$, and Rodney Forster ${ }^{2,4}$ \\ ${ }^{1}$ Met Office, FitzRoy Road, Exeter, EX1 3PB, UK \\ ${ }^{2}$ Centre for Environment, Fisheries and Aquaculture Science (Cefas), Pakefield Road, Lowestoft, NR33 0HT, UK \\ ${ }^{3}$ Royal Netherlands Institute for Sea Research (NIOZ), Department of Coastal Systems and Utrecht University, \\ P.O. Box 59, 1790 AB Den Burg, Texel, the Netherlands \\ ${ }^{4}$ University of Hull, Cottingham Road, Hull, HU6 7RX, UK
}

Correspondence to: David A. Ford (david.ford@metoffice.gov.uk)

Received: 21 July 2016 - Discussion started: 25 July 2016

Revised: 20 December 2016 - Accepted: 11 January 2017 - Published: 21 March 2017

\begin{abstract}
Phytoplankton form the base of the marine food chain, and knowledge of phytoplankton community structure is fundamental when assessing marine biodiversity. Policy makers and other users require information on marine biodiversity and other aspects of the marine environment for the North Sea, a highly productive European shelf sea. This information must come from a combination of observations and models, but currently the coastal ocean is greatly under-sampled for phytoplankton data, and outputs of phytoplankton community structure from models are therefore not yet frequently validated. This study presents a novel set of in situ observations of phytoplankton community structure for the North Sea using accessory pigment analysis. The observations allow a good understanding of the patterns of surface phytoplankton biomass and community structure in the North Sea for the observed months of August 2010 and 2011. Two physical-biogeochemical ocean models, the biogeochemical components of which are different variants of the widely used European Regional Seas Ecosystem Model (ERSEM), were then validated against these and other observations. Both models were a good match for sea surface temperature observations, and a reasonable match for remotely sensed ocean colour observations. However, the two models displayed very different phytoplankton community structures, with one better matching the in situ observations than the other. Nonetheless, both models shared some similarities with the observations in terms of spatial features and interannual variability. An initial comparison of the formulations
\end{abstract}

and parameterizations of the two models suggests that diversity between the parameter settings of model phytoplankton functional types, along with formulations which promote a greater sensitivity to changes in light and nutrients, is key to capturing the observed phytoplankton community structure. These findings will help inform future model development, which should be coupled with detailed validation studies, in order to help facilitate the wider application of marine biogeochemical modelling to user and policy needs.

\section{Introduction}

Marine biogeochemical model complexity has long been a subject of debate (e.g. Anderson, 2005). Simpler models require fewer, often better understood parameterizations, but omit processes which are known to be important. More complex models explicitly include these processes, but require an increased number of tuneable parameters, the ranges of which are often poorly constrained by observations and/or poorly defined where they aggregate over a range of species. No consensus exists within the scientific community, but recent studies have shown that simple to moderately complex models still do the best job of reproducing basic biogeochemical descriptors such as primary production and carbon fluxes (Kwiatkowski et al., 2014; Friedrichs et al., 2007; Ward et al., 2013; Xiao and Friedrichs, 2014). Further studies have suggested that "Models of Intermediate Complexity for Ecosys- 
tem assessments" are the most appropriate for fisheries management (Plagányi et al., 2014).

Ultimately, models are tools, and the most appropriate tool should be chosen for the task at hand; different scientific, societal, and managerial questions will require models of different complexities. For instance, describing a complex coastal environment will likely require the explicit inclusion of processes which are less important when considering global-scale carbon budgets. Furthermore, some users require more detailed information about the marine environment than simple models can provide, necessitating the use of more complex models.

This demand for detailed information applies to the North Sea, with users and policy makers requiring information about topics including eutrophication and nutrient ratios (Skogen et al., 2014), productivity in relation to fisheries (Chassot et al., 2007), harmful and nuisance algal blooms (Blauw et al., 2010; Kurekin et al., 2014), water clarity (Dupont and Aksnes, 2013; Capuzzo et al., 2015), biodiversity (Brandsma et al., 2013), effects of climate change (van der Molen et al., 2013; Wakelin et al., 2015a), effects of trawling (Allen and Clarke, 2007; van der Molen et al., 2013), and impacts of marine renewable energy generation (van der Molen et al., 2014, 2016). In particular, indicators of Good Environmental Status (GES) are required in the context of the Marine Strategy Framework Directive (MSFD; Borja et al., 2013). These include descriptors of food-web structure, trophic status, and biodiversity, and elements of these can be assessed with various modelling approaches (Piroddi et al., 2015; Hyder et al., 2015).

Ecosystem models are central to the delivery of marine ecosystem-based management that is specified in existing legislation (MSFD - EU, 2008; CFP - EU, 2013; WFD - EU, 2000). These models are important for the design of management measures and to assess the social, economic, and environmental performance of management in relation to targets (Defra, 2014; Sutherland et al., 2006). This is done through improving our understanding of the links between pressures (human and environmental) and the response of the system to these pressures. However, ecosystem models are not used frequently in the UK and Europe in support of policy and management (Hyder et al., 2015), despite increasing use in the USA and Australia (Fulton and Link, 2014; Fulton et al., 2007). For models to have a larger impact on policy development and decision-making, modelling approaches need to be more transparent, verifiable, and repeatable than they are at present, as any outputs can be subject to legal challenge (Hyder et al., 2015). Poor uptake of ecosystem models by decision-makers is due to a lack of confidence in and understanding of models. This relates to how models are used, terminology, type of outputs, treatment of uncertainty, required quality standards, and the presentation of model products (Hyder et al., 2015). The use of ecosystem models will become increasingly important as the complexity of marine legislation increases (Boyes and Elliott, 2014). Hence, sim- ple assessment of the skill of models in predicting outcomes (validation - Mackinson, 2014), model comparisons (e.g. Kwiatkowski et al., 2014), and the clear treatment of the uncertainty associated with predictions (Thorpe et al., 2015; Gårdmark et al., 2013; Stewart and Martell, 2015; Tebaldi and Knutti, 2007) are needed to increase the confidence in and uptake of models (Hyder et al., 2015).

At the base of the marine food chain are phytoplankton, and phytoplankton community structure is a fundamental consideration in any assessment of marine biodiversity (Garmendia et al., 2013). Changes in community structure can result from large-scale environmental changes such as temperature rises or eutrophication, with different organisms favouring different conditions. Some organisms that favour changed conditions may be harmful to human health (Roselli and Basset, 2015; Bruggeman, 2009). Alternatively, topdown control by benthic or pelagic grazers can change the size structure of phytoplankton by selective removal of larger species, resulting for instance in an increased proportion of pico-phytoplankton in areas with dense shellfish aquaculture (Smaal et al., 2013). Phytoplankton vary in size by up to 9 orders of magnitude for cell volume (Finkel et al., 2010), with variations in community structure reflected in the size and species of their predators, and the number of links in the food chain (Ryther, 1969; Chavez et al., 2011). Larger cells such as diatoms are consumed directly by copepod grazers, giving a higher transfer of energy and ultimately impacting commercial fish stocks (Jennings and Collingridge, 2015). As the physical structure of the North Sea becomes increasingly well understood due to advances in hydrodynamic modelling (van Leeuwen et al., 2015) and availability of long-term observations (Greenwood et al., 2010; Núñez-Riboni and Akimova, 2015), the potential to predictively model plankton population structure and distribution increases as well.

A common way to model plankton community structure is to take a phytoplankton functional type (PFT) approach, such as is done in variants of the European Regional Seas Ecosystem Model (ERSEM; Baretta et al., 1995). This approach groups phytoplankton into a number of PFTs, based on their general function within the ecosystem (Le Quéré et al., 2005). If information on phytoplankton community structure is to be modelled and provided to users, then it must be validated. Some studies have aimed to validate this against observations (Lewis et al., 2006; Gregg and Casey, 2007; Lewis and Allen, 2009; Hirata et al., 2013), but commonly validation studies go no further than total chlorophyll concentration (Edwards et al., 2012; de Mora et al., 2013). This is largely because there is a lack of observations that contain more detail about community structure against which to compare. Algorithms for deriving phytoplankton community structure from remotely sensed satellite ocean colour observations, either in the form of PFTs or phytoplankton size classes (PSCs), are being developed (Brewin et al., 2011; Brito et al., 2014), but have not yet reached maturity and are not yet widely available to the general scientific commu- 
nity. Moreover, such remote-sensing products require a similar level of validation (Brotas et al., 2013). In situ observations are sparse, particularly in shelf seas, and the measured variables may not be easily matched to model outputs, which do not always aggregate neatly over species or size classes.

This study presents a novel set of in situ observations of phytoplankton community structure in the North Sea using accessory pigment analysis (Sherrard et al., 2006), noting that coastal seas are greatly under-represented in the existing global collection of pigment data (Peloquin et al., 2013). Pigment data were analysed so as to give the relative distribution of different size classes, allowing a robust comparison with outputs from ERSEM-type models. Two variants of ERSEM, run by the Centre for Environment, Fisheries and Aquaculture Science (Cefas) and the Met Office, both public bodies in the UK, were validated against these and other observations. The aims of the study were to determine what these new observations add to current scientific understanding of North Sea biogeochemistry, assess the extent to which the models can reproduce the observations, and discuss the implications for current and future user and policy needs, observing strategies and model development.

\section{Observations}

\subsection{International Bottom Trawl Survey (IBTS)}

The International Bottom Trawl Survey (IBTS) is a multinational ecological research effort established by the International Council for the Exploration of the Sea (ICES) in the early 1970s. Surveys using fisheries research vessels currently take place in the first and third quarter of the year and cover the entire North Sea, using standardized sampling gears and protocols. With cruise lengths of typically 6-8 weeks, each vessel undertakes a gridded survey of the North Sea, repeated each year, in which stations are sampled for groundfish (the primary target of the survey), but also secondary targets such as benthos, seabed litter, and hydrographic parameters. Individual station sampling is often accompanied by visual seabird and cetacean estimates, underway acoustics, and online monitoring of near-surface water quality using FerryBox-type instruments (Petersen et al., 2008). The IBTS thus fits the needs of a multi-disciplinary survey capable of collecting data on human pressures and ecosystem responses for legislation such as the MSFD (http://www.jpi-oceans.eu/ multi-use-infrastructure-monitoring). The open data policy of ICES has resulted in many significant publications in fisheries research (Jennings et al., 2002; Daan et al., 2005) and fisheries policy (Rombouts et al., 2013; Shephard et al., 2015).

Prior to 2010, phytoplankton had not been systematically sampled on the UK IBTS. Advances in the autonomous sampling and detection of particles in the water column (e.g. online flow cytometry, Thyssen et al., 2015), and also the need for high-quality in situ data for validation of satellite remote-sensing data, indicated that the addition of phytoplankton to the survey would be beneficial. Hence, sampling of PFTs using high-pressure liquid chromatography (HPLC - pigment fingerprinting), and analytical flow cytometry (results reported elsewhere) were initiated on the third quarter IBTS cruise of the RV Cefas Endeavour in AugustSeptember 2010 and subsequent years.

Seawater samples from depths of $4 \mathrm{~m}$ ("surface") were collected using $10 \mathrm{~L}$ Niskin bottles when weather conditions permitted, or from the ship's bow-intake flow-through clean seawater supply during adverse weather conditions. A known amount of water, typically $1000 \mathrm{~mL}$, was passed through a $200 \mu \mathrm{m}$ gauze to remove larger zooplankton and debris, then filtered within $1 \mathrm{~h}$ on $47 \mathrm{~mm}$ GFF filters, which were folded in half, wrapped in aluminium foil and snap frozen in liquid nitrogen dry shippers. On return to shore, samples were transferred to a $-80^{\circ} \mathrm{C}$ freezer for a storage period of $1-$ 2 months before shipping of samples on dry ice to an accredited HPLC laboratory (DHI Water Quality Institute; Horsholm, Denmark) for chlorophyll $a$ (Chl $a$ ) quantification and full accessory pigment analysis (Schlüter et al., 2011).

Pigment data from the surface stations were quality controlled in several steps: first, with an initial comparison of HPLC Chl $a$ against independent measures of chlorophyll fluorescence from the fluorometers on the ship's FerryBox and CTD system. This step corrected a small number of mislabelled samples. In a second step, anomalies within a sample were detected using methods described by Aiken et al. (2009), e.g. regression of total accessory pigments against Chl $a$ concentration and search for outliers.

Diagnostic pigment analysis was then used on the qualitycontrolled data set to relate the composition of specific accessory pigments to the relative contribution of different size classes to the total phytoplankton biomass. The designation of specific accessory pigments to algal taxonomic groups of different size, e.g. fucoxanthin and peridinin for large-cell diatoms and dinoflagellates, has been widely established in the biological oceanographic literature (Uitz et al., 2006, 2008). The equations used to estimate the contribution of pico-phytoplankton $(0-2 \mu \mathrm{m})$, nano-phytoplankton $(2-20 \mu \mathrm{m})$ and micro- or net phytoplankton $(>20 \mu \mathrm{m})$ were later modified by Hirata et al. $(2008,2011)$ and Brewin et al. (2010). The various methods differ in the degree to which the marker pigments chlorophyll $b(\mathrm{Chl} b)$ and 19-hexfucoxanthin (19-hex) are attributed to the three size classes. Here, Chl $b$ and 19-hex were assigned equally to the picophytoplankton and nano-phytoplankton size classes. Picophytoplankton are therefore represented by zeaxanthin, Chl $b$, and 19-hex; nano-phytoplankton are represented by 19hex, 19-but, alloxanthin, and $\mathrm{Chl} b$; and micro-phytoplankton are represented by fucoxanthin and peridinin. Results are expressed as a proportion of the total Chl $a$ concentration for each station. 
Table 1. Summary of general-level model characteristics.

\begin{tabular}{|c|c|c|}
\hline & NEMO-ERSEM & GETM-ERSEM-BFM \\
\hline Hydrodynamics & NEMO & GETM \\
\hline Biogeochemistry & ERSEM & ERSEM-BFM \\
\hline Domain & Northwest European Shelf & North Sea \\
\hline Horizontal resolution & $\sim 7 \mathrm{~km}$ & $\sim 10 \mathrm{~km}$ \\
\hline Vertical resolution & $\begin{array}{l}50 \text { levels, terrain-following with constant } 1 \mathrm{~m} \text { top } \\
\text { box }\end{array}$ & $\begin{array}{l}25 \text { levels, terrain-following general vertical coordi- } \\
\text { nates }\end{array}$ \\
\hline Tidal boundary & $\begin{array}{l}\text { Elevation and currents from Met Office global } \\
\text { model, Flather radiation condition }\end{array}$ & $\begin{array}{l}\text { Elevations and currents from shelf model, Flather } \\
\text { radiation condition }\end{array}$ \\
\hline $\begin{array}{l}\text { Temperature and salin- } \\
\text { ity boundary }\end{array}$ & Met Office global model (GloSea5 reanalysis) & ECMWF global model \\
\hline Nutrients boundary & World Ocean Atlas climatology & World Ocean Atlas climatology \\
\hline Meteorological forcing & $\begin{array}{l}\text { ECMWF ERA-Interim reanalysis: surface tempera- } \\
\text { ture, } 2 \mathrm{~m} \text { wind, air pressure, heat fluxes, precipita- } \\
\text { tion; 3-hourly }\end{array}$ & $\begin{array}{l}\text { ECMWF ERA- } 40 \text { and operational hindcast: sur- } \\
\text { face temperature, } 10 \mathrm{~m} \text { wind, air pressure, humidity, } \\
\text { cloud cover; } 6 \text {-hourly }\end{array}$ \\
\hline $\begin{array}{l}\text { Atmospheric nutrient } \\
\text { deposition }\end{array}$ & Not included & Not included \\
\hline River inputs & $\begin{array}{l}\text { Freshwater flow: E-Hype; nutrients: climatology; } \\
\text { sediments: daily climatology of satellite SPM at } \\
\text { river points }\end{array}$ & $\begin{array}{l}\text { Cefas database, interpolated daily values of runoff } \\
\text { and nutrients based on various observational } \\
\text { sources }\end{array}$ \\
\hline SPM concentrations & $\begin{array}{l}\text { Modelled, two size classes, full transport, resuspen- } \\
\text { sion, aggregation and disaggregation }\end{array}$ & $\begin{array}{l}\text { Modelled, one size class with concentration- } \\
\text { dependent settling, full transport, resuspension by } \\
\text { waves and currents }\end{array}$ \\
\hline Nutrients & N, P, Si, C, O (Fe available but not used) & $\mathrm{N}, \mathrm{P}, \mathrm{Si}, \mathrm{C}, \mathrm{O}$ reduction equivalents \\
\hline $\begin{array}{l}\text { Pelagic autotrophic } \\
\text { types }\end{array}$ & $\begin{array}{l}\text { Diatoms, flagellates, dinoflagellates, picophyto- } \\
\text { plankton }\end{array}$ & $\begin{array}{l}\text { Diatoms, flagellates, dinoflagellates, picophyto- } \\
\text { plankton, Phaeocystis colonies, resuspended ben- } \\
\text { thic diatoms, pelagic nitrifiers }\end{array}$ \\
\hline $\begin{array}{l}\text { Zooplankton functional } \\
\text { types }\end{array}$ & $\begin{array}{l}\text { Mesozooplankton, microzooplankton, het- } \\
\text { erotrophic nanoflagellates }\end{array}$ & $\begin{array}{l}\text { Filter feeder larvae, mesozooplankton, omnivorous } \\
\text { mesozooplankton, microzooplankton, heterotrophic } \\
\text { nanoflagellates }\end{array}$ \\
\hline Pelagic bacteria & Pelagic bacteria & Pelagic bacteria \\
\hline Pelagic detritus & $\begin{array}{l}\text { Labile dissolved organic matter, semi-labile dis- } \\
\text { solved organic matter, small particulate organic } \\
\text { matter, medium particulate organic matter, large } \\
\text { particulate organic matter }\end{array}$ & $\begin{array}{l}\text { Labile organic carbon, TEP, particulate organic car- } \\
\text { bon (POC). Degradability of POC depends on nu- } \\
\text { trient: C quota. Vertical exchange of POC coupled } \\
\text { to SPM transport. }\end{array}$ \\
\hline Type of benthic model & $\begin{array}{l}\text { 3-layer model: oxic layer, denitrification layer, } \\
\text { anoxic layer }\end{array}$ & $\begin{array}{l}\text { 3-layer model: oxic layer, denitrification layer, } \\
\text { anoxic layer }\end{array}$ \\
\hline Seabed characterization & $\begin{array}{l}\text { Distribution of the two modelled SPM size classes, } \\
\text { dependent on model dynamics }\end{array}$ & $\begin{array}{l}\text { Porosity interpolated from North Sea Benthos Sur- } \\
\text { vey grain size data }\end{array}$ \\
\hline $\begin{array}{l}\text { Benthic autotrophic } \\
\text { types }\end{array}$ & Not included & $\begin{array}{l}\text { Benthic diatoms, benthic nitrifying bacteria, nitrify- } \\
\text { ing archaea }\end{array}$ \\
\hline Benthic macrofauna & Deposit feeders, suspension feeders, meiobenthos & $\begin{array}{l}\text { Epibenthos, deposit feeders, filter feeders, meioben- } \\
\text { thos, benthic predators }\end{array}$ \\
\hline
\end{tabular}


Table 1. Continued.

\begin{tabular}{|c|c|c|}
\hline & NEMO-ERSEM & GETM-ERSEM-BFM \\
\hline Benthic bacteria & Aerobic bacteria, anaerobic bacteria & Aerobic bacteria, anaerobic bacteria \\
\hline Benthic detritus & $\begin{array}{l}\text { Dissolved organic matter, particulate organic mat- } \\
\text { ter, buried organic matter }\end{array}$ & Labile organic carbon, particulate organic carbon \\
\hline $\mathrm{CO}_{2}$ method & Available but not used & Benthic and pelagic $\mathrm{CO}_{2}, \mathrm{pH}$, alkalinity \\
\hline $\begin{array}{l}\text { Pelagic nutrient regen- } \\
\text { eration }\end{array}$ & $\begin{array}{l}\text { Nitrification depends on dynamics of nitrifying bac- } \\
\text { teria }\end{array}$ & $\begin{array}{l}\text { Nitrification depends on dynamics of nitrifying ar- } \\
\text { chaea and bacteria }\end{array}$ \\
\hline $\begin{array}{l}\text { Benthic nutrient regen- } \\
\text { eration }\end{array}$ & $\begin{array}{l}\text { Modelling of fluxes based on estimation of nutrient } \\
\text { gradients on basis of processes and concentrations } \\
\text { in the } 3 \text { benthic layers }\end{array}$ & $\begin{array}{l}\text { Modelling of fluxes based on estimation of nutrient } \\
\text { gradients on basis of processes and concentrations } \\
\text { in the three benthic layers for phosphate, ammo- } \\
\text { nium, nitrate, reduction equivalents, silicate, DIC, } \\
\text { alkalinity. Dynamic determination of nitrification } \\
\text { rate from benthic nitrifier model. }\end{array}$ \\
\hline Spinup period & $\begin{array}{l}\text { Previous hindcast of Edwards et al. (2012), run for } \\
2007 \text { from previously spun-up fields }\end{array}$ & $1991-2001$ \\
\hline Production run & $\begin{array}{l}2003-2012 \text { (also run for } 1983-1989 \text { and } 1989- \\
2003 \text {, but sections not continuous) }\end{array}$ & $2002-2011$ \\
\hline Data assimilation & Satellite and in situ SST; 3D-Var & Not included \\
\hline References & Blackford et al. (2004); Edwards et al. (2012) & $\begin{array}{l}\text { Baretta et al. (1995); Ruardij and van Raaphorst } \\
\text { (1995); van der Molen et al. (2016) }\end{array}$ \\
\hline
\end{tabular}

\subsection{Other validation data}

As well as the IBTS data introduced in this study, other observation-based products have been used for model validation. Sea surface temperature (SST) has been validated against OSTIA (Operational Sea Surface Temperature and Sea Ice Analysis; Donlon et al., 2012), which is an objective analysis product based on remotely sensed and in situ SST observations. Sea surface chlorophyll and suspended particulate matter (SPM) have been validated against remotely sensed ocean colour products from the Medium Resolution Imaging Spectrometer (MERIS) and Moderate Resolution Imaging Spectroradiometer (MODIS) sensors, developed by Ifremer using the OC5 algorithm (Gohin et al., 2002, 2005, 2008). Due to the limited availability of observations, nutrient concentrations have been validated against the $1^{\circ}$ resolution World Ocean Atlas climatologies (Garcia et al., 2010).

\section{Models}

Two different physical-biogeochemical modelling systems were used in this study: GETM-ERSEM-BFM, run by Cefas, and NEMO-ERSEM, run by the Met Office. Each is described in turn below, followed by a discussion of their differences and similarities. Existing configurations of each model were used, with no attempt made to increase their similarity. Details of the model configurations and forcing are given in
Table 1, and the model domains and bathymetries are shown in Fig. 1.

\subsection{GETM-ERSEM-BFM}

GETM (General Estuarine Transport Model) is a public domain, three-dimensional (3-D) finite difference hydrodynamical model (Burchard and Bolding, 2002; available through http://www.getm.eu). It solves the 3-D partial differential equations for conservation of mass, momentum, salt, and heat. The ERSEM-BFM (European Regional Seas Ecosystem Model - Biogeochemical Flux Model) version used here is a development of the model ERSEM III (see Baretta et al., 1995; Ruardij and van Raaphorst, 1995; Ruardij et al., 1997, 2005; Vichi et al., 2003, 2004, 2007; van Leeuwen et al., 2013; van der Molen et al., 2013, 2014, 2016), and describes the dynamics of the biogeochemical fluxes within the pelagic and benthic environment. The ERSEM-BFM model simulates the cycles of carbon, nitrogen, phosphorus, silicate, and oxygen, and allows for variable internal nutrient ratios inside organisms, based on external availability and physiological status. The model applies a functional group approach and contains six phytoplankton groups, four zooplankton groups, and five benthic groups, the latter comprising four macrofauna and one meiofauna groups. Pelagic and benthic aerobic and anaerobic bacteria are also included. The pelagic module includes a number of processes in addition to those included in the oceanic version presented by Vichi 
et al. (2007) to make it suitable for temperate shelf seas: (i) a parameterization for diatoms allowing growth in spring, (ii) enhanced transparent exopolymer particles (TEP) excretion by diatoms under nutrient stress, (iii) the associated formation of macro-aggregates consisting of TEP and diatoms, leading to enhanced sinking rates and a sufficient food supply to the benthic system especially in the deeper offshore areas (Engel, 2000), (iv) a Phaeocystis functional group for improved simulation of primary production in coastal areas (Peperzak et al., 1998; Ruardij et al., 2005), (v) a new resuspension module for inorganic fine SPM that responds to combined currents and surface waves, and uses a concentrationdependent settling velocity for improved simulation of the under-water light climate (van der Molen et al., 2017), and (vi) resuspension of particulate organic material, in proportion to the resuspended inorganic SPM and the relative concentrations of organic and fine inorganic matter in the sea bed. The model includes a three-layer benthic module comprising 53 state variables, which enables it to resolve a high level of detail of benthic processes and benthic-pelagic coupling. New features of the benthic model are: (i) benthic diatoms, and (ii) active oxygen uptake of deposit feeders from the water column. The first four additional pelagic processes listed above are related, and based on detailed implementation of the dynamic model of phytoplankton growth, explicit chlorophyll content, and acclimation of Geider et al. (1997). In nutrient-enriched coastal zones, the competition between and seasonal succession of PFTs is influenced strongly by differences in their photosynthetic capability. The modelled photosynthesis and phytoplankton carbon and chlorophyll content follows Geider et al. (1997) closely, by first calculating light-saturated and nutrient-replete photosynthesis. In the second stage, light-adapted chlorophyll content is calculated and light limitation and nutrient limitation are applied. These result in changes in the chlorophyll : carbon ratio, and growth. Photo-inhibition is included explicitly in the chlorophyll calculations, and carbon uptake is calculated before applying nutrient limitation. Under nutrient-limited conditions, diatoms excrete the excess carbon as TEP, which is modelled as a separate state variable. Phaeocystis cells, implemented as a simplified version of the model of Ruardij et al. (2005), excrete TEP within the colony. Implicit macroaggregate sinking rates are calculated as a linear proportion of a prescribed maximum sinking rate, governed by stickiness rates related to the concentrations of diatoms, TEP, and the level of nutrient stress, and also induce sinking of other PFTs. Because the initial slope of the $P-I$ curve $\alpha_{\mathrm{chl}}$, the light-saturated carbon-specific photosynthesis rate $P_{\mathrm{m}}^{\mathrm{C}}$, the saturation parameter for the growth-irradiance curve $K_{\mathrm{I}}$, and the maximum chlorophyll : carbon ratio $\theta_{\mathrm{m}}$ are related (Geider et al., 1997) through

$\alpha_{\mathrm{chl}}=\frac{P_{\mathrm{m}}^{\mathrm{C}}}{\theta_{\mathrm{m}} K_{\mathrm{I}}}$
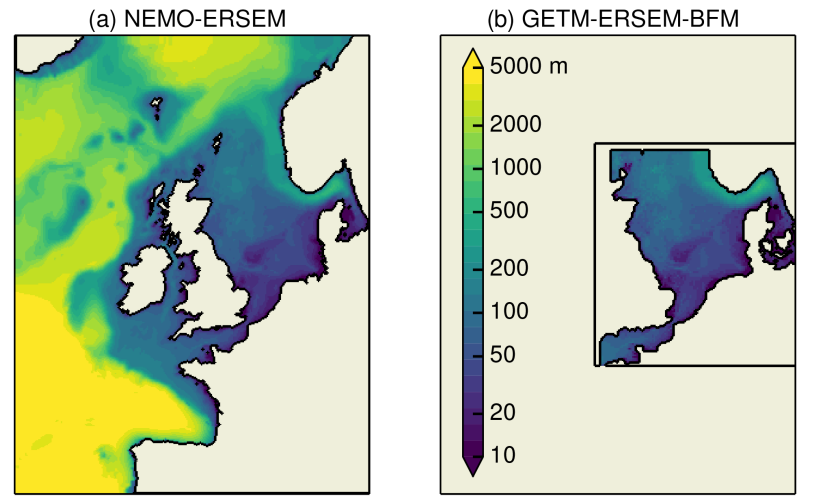

Figure 1. Maps of the model domain and bathymetry for (a) NEMO-ERSEM and (b) GETM-ERSEM-BFM.

and $K_{\mathrm{I}}$ can be approximated by the light intensity at maximum photosynthetic rate $\left(K_{\mathrm{E}}\right)$, so $K_{\mathrm{E}}$ was used to prescribe light sensitivity. Values were selected to simulate observed successions in the Dutch coastal zone (Table 2).

The model setup for the North Sea uses a spherical grid with a spatial resolution of approximately $11 \mathrm{~km}$ and 25 layers in the vertical (Lenhart et al., 2010; van der Molen et al., 2014, 2015). The model was forced with tidal boundary conditions from a shelf-scale model, temperature and salinity boundary conditions from a global hindcast (ECMWF-ORAS4; Balmaseda et al., 2013; Mogensen et al., 2012), climatological nutrient boundary conditions, observations-based river run-off, and riverine nutrient loads (the National River Flow Archive (data available at http://www.ceh.ac.uk/data/nrfa/index.html) for UK rivers, the Agence de l'eau Loire-Bretagne, Agence de l'eau SeineNormandie and IFREMER for French rivers, the DONAR database for Netherlands rivers, ARGE Elbe, the Niedersächsisches Landesamt für Ökologie, and the Bundesanstalt für Gewässerkunde for German rivers, and the Institute for Marine Research, Bergen, for Norwegian rivers; see also Lenhart et al., 2010), and atmospheric forcing from the ECMWF ERA-40 and operational hindcast (ECMWF, 2006a, b).

\subsection{NEMO-ERSEM}

The hydrodynamic component of the Met Office modelling system is NEMO (Nucleus for European Modelling of the Ocean; Madec, 2008). NEMO is an open source community model originally developed for global ocean modelling (e.g. Storkey et al., 2010), but which has also been recently developed for use in shelf seas (O'Dea et al., 2012). The version used in this study (CO5; O'Dea et al., 2017) is based on NEMO v3.4, and is a development of that described in O'Dea et al. (2012) and Edwards et al. (2012). The main updates from O'Dea et al. (2012) are an upgrade from NEMO v3.2 to v3.4, an increase in vertical resolution from 33 to 51 levels 


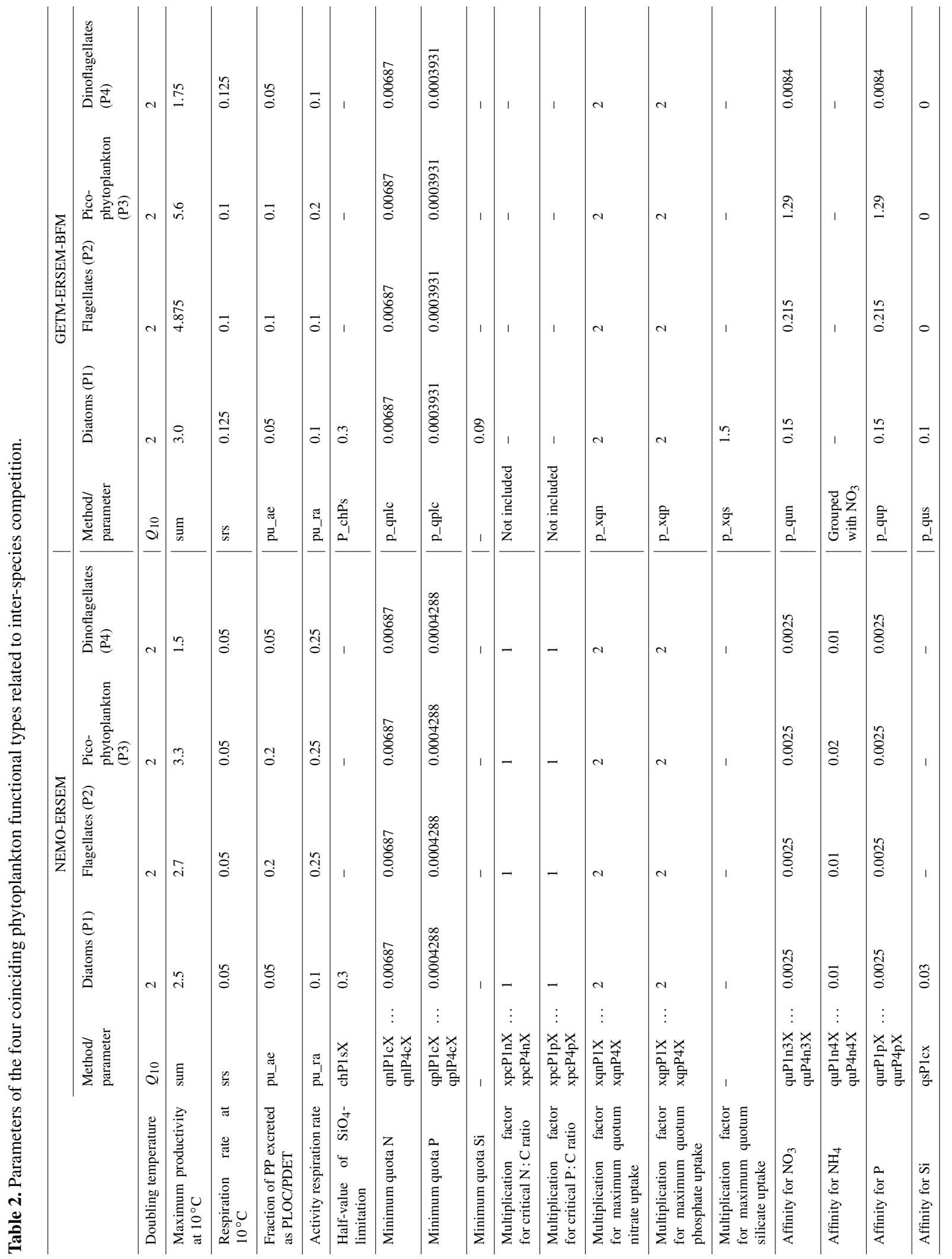







and change of coordinate stretching function, changes to the river inputs and Baltic boundary condition, a change of data assimilation scheme from analysis correction to 3D-Var, and the use of bulk formulae to calculate the input atmospheric fluxes rather than direct forcing. These updates are described further below.

The version of ERSEM used is an alternative development of the original code of Baretta et al. (1995), led by Plymouth Marine Laboratory (PML), and is described in detail by Blackford et al. (2004) and Edwards et al. (2012). The pelagic component includes four phytoplankton and three zooplankton functional groups, and one bacterial group. The benthic component includes aerobic and anaerobic bacteria, suspension feeders, bottom feeders, and the meiobenthos. This version follows the photoacclimation model of Geider et al. (1997) in an adapted form, in which nutrient limitation is applied before the other calculations, leading to much lower estimates of excess carbon, which is excreted as detritus. Photoinhibition is included as an additional parameterization in the photoacclimation method. SPM is simulated as per Sykes and Barciela (2012).

As part of the Forecasting Ocean Assimilation Model (FOAM; Blockley et al., 2014) suite of models, NEMOERSEM is run operationally at the Met Office on a daily basis, providing 5-day forecasts of physical and biogeochemical variables for the Northwest European Shelf seas. Analyses and forecasts are publicly available through the Copernicus Marine Environment Monitoring Service (CMEMS; $\mathrm{http}: / /$ marine.copernicus.eu), which is the operational service building on the MyOcean project. Physical and biogeochemical reanalysis products (Wakelin et al., 2015b) are also available through CMEMS, and results from the recent NEMOERSEM reanalysis were used in this study.

The model was run on the $7 \mathrm{~km}$ resolution Atlantic Meridional Margin (AMM7) domain, covering the entire Northwest European Shelf seas, including the North Sea. There are 51 vertical levels, using a hybrid $\sigma-\mathrm{S}$ coordinate system with the stretching function of Siddorn and Furner (2013). This uses terrain-following coordinates whilst ensuring a fixed surface resolution of $1 \mathrm{~m}$. Remotely sensed and in situ observations of SST were assimilated using a 3D-Var implementation of the NEMOVAR data assimilation scheme (Waters et al., 2015; O'Dea et al., 2012). River inputs were taken from the E-HYPE model (Donnelly et al., 2015) for flow values, and from the same climatology as in Edwards et al. (2012) for nutrients and SPM. Lateral boundary conditions for physical variables were taken from a reanalysis of the GloSea5 seasonal forecasting system (MacLachlan et al., 2014) at the Atlantic boundaries, and from the IOW-GETM model (Stips et al., 2004) at the Baltic boundary. For biogeochemistry, lateral boundary conditions for nitrate, phosphate, and silicate were taken from the World Ocean Atlas monthly climatology (Garcia et al., 2010) at the Atlantic boundaries, and zero flux boundary conditions were applied at the Baltic boundary. Zero flux boundary conditions were applied for all other biogeochemical variables at all boundaries. Surface forcing was from the ERA-Interim reanalysis (Dee et al., 2011). The NEMO-ERSEM reanalysis covers the period January 1985 to July 2012, but for practical reasons was run in three sections. The final section, which this study uses, started in November 2003, with physics initial conditions taken from the corresponding date of a non-assimilative hindcast of the entire reanalysis period. Biogeochemical initial conditions were taken from a winter date of the run of NEMO-ERSEM described in Edwards et al. (2012).

\subsection{Comparison of the two models}

Even though both models used versions of ERSEM, it is reasonable to expect differences in the results. Such differences are inevitably a result of the accumulation of differences between the models. It should be noted that both models were run as usual, and no attempts were made to increase similarity. It is recognized that this means definitive conclusions cannot be reached here on the exact reasons behind differences in results, and this was not the aim of this study. A preliminary discussion is provided here, with more detailed follow-on experiments proposed in Sect. 5. To help understand the differences in model behaviour, this section summarizes the main differences between the two models. We focus on two types of differences: general level differences (Table 1), and differences in phytoplankton parameters and parameterizations (Table 2). For the sake of readability, and to limit repetition, the following summary is kept at a fairly basic level; for (numerical) detail the reader is referred to the tables.

The two hydrodynamics models were different, and in general used different domains, resolutions, and forcing data. The NEMO-ERSEM model had a larger domain (Fig. 1), at higher resolution, and used more advanced atmospheric forcing. Moreover, in NEMO-ERSEM, SST was assimilated, while GETM-ERSEM-BFM had no data assimilation. NEMO-ERSEM's river runoff originated from a model, that of GETM-ERSEM-BFM from observations. The GETMERSEM-BFM model used time series of riverine nutrient inputs whereas the NEMO-ERSEM model used a climatology. The SPM model of NEMO-ERSEM contained explicit size fractions and cohesive interactions, but was only forced by flow velocities, while that of the GETM-ERSEMBFM model was non-cohesive, with implicit size-related behaviour and included resuspension by both currents and waves (van der Molen et al., 2017). The models also used different initial conditions and spin-up sequences.

Both ERSEM versions share a common origin, both use the same base nutrients $(\mathrm{N}, \mathrm{P}, \mathrm{Si}, \mathrm{C})$, and are both based on a functional type approach. They share four phytoplankton types, three zooplankton types, and a basic bacteria type. Both have a three-layered benthic module, with similar nutrient regeneration mechanisms. 
GETM-ERSEM-BFM had a number of additional functional types compared to NEMO-ERSEM: Phaeocystis colonies, benthic diatoms, carnivorous zooplankton, filter feeder larvae, epibenthos, benthic predators, and benthic and pelagic nitrifying bacteria. Furthermore, it used a $\mathrm{CO}_{2}$ module, whereas in NEMO-ERSEM this was switched off.

The models used different methods for nutrient affinity, nutrient stress and sinking, and light susceptibility. For nutrient affinity, GETM-ERSEM-BFM used 10-100 times higher affinity values for nutrient uptake. There are two ways to measure phytoplankton nutrient uptake in experiments (Veldhuis and Admiraal, 1987): (i) a short-duration experiment in which nutrients are added to nutrient-deprived algal cultures and uptake rates into the internal nutrient buffer are measured; and (ii) an experiment that lasts a full day in which uptake rates needed for daily growth are measured. The parameters for GETM-ERSEM-BFM were based on short-duration experiments, whereas those for NEMO-ERSEM were based on long-duration experiments. The short-duration parameterization allows for improved incorporation of the dependencies of cell properties such as cell size and buffer capacity. These features were needed to resolve the competition between diatoms and Phaeocystis colonies during excessive spring blooms in the Dutch coastal zone, which terminate through phosphate depletion. In GETM-ERSEM-BFM, nutrient stress of pelagic diatoms leads to excretion of all (new fixated) organic $\mathrm{C}$ that cannot be used for growth as carbohydrates (TEP). At high levels of diatoms, this excretion leads to the simulation of the effect of macro-aggregate formation through binding by these carbohydrates, through increases in the sinking rate of live and dead particulate matter. NEMO-ERSEM used a more implicit approach to sinking. For light susceptibility, both models used a photosynthesisirradiance $(P-I)$ curve approach, but NEMO-ERSEM defined it through the initial slope (alpha), whereas GETMERSEM-BFM defined it through the light intensity at maximum photosynthetic rate $\left(K_{\mathrm{E}}\right)$. For several elements where both models used the same approach, parameter settings were different: maximum productivity, respiration, excretion, minimum quota for $\mathrm{P}$, lysis, and $\mathrm{C}: \mathrm{Chl}$ ratios. For these, there was typically more differentiation in settings between phytoplankton functional types in GETM-ERSEMBFM than in NEMO-ERSEM.

\subsection{Aggregating model PFTs to match observed PSCs}

To allow validation of phytoplankton community structure from the models against the IBTS observations, the four PFTs from NEMO-ERSEM and six PFTs from GETMERSEM-BFM must be appropriately aggregated to match the observed PSCs. Diatoms (both models), dinoflagellates (both models) and resuspended benthic diatoms (GETM-ERSEM-BFM only) were considered to be microphytoplankton. Flagellates (both models) and Phaeocystis colonies (GETM-ERSEM-BFM only) were considered to be nano-phytoplankton. The pico-phytoplankton PFT (both models) was directly mapped to the pico-phytoplankton PSC. For consistency with the IBTS observations, the PFTs and PSCs were expressed as fractions of total chlorophyll concentration, rather than biomass.

\section{Results}

\subsection{Observations}

Each year, the IBTS cruise starts in early August in the Southern Bight of the North Sea off the Thames Estuary $\left(51.5^{\circ} \mathrm{N}\right)$ and proceeds northwards via a series of longitudinal transects, with each transect taking 1-3 days, depending upon the width of the North Sea at each point. The final transect between the Shetland Islands and Norway at $61^{\circ} \mathrm{N}$ was reached by early September for the 2010 and 2011 IBTS cruises. The spatially averaged annual mean surface temperature for the North Sea was $9.9{ }^{\circ} \mathrm{C}$ in 2010 and $10.0^{\circ} \mathrm{C}$ in 2011 , which were very close to the long-term average of $10.0^{\circ} \mathrm{C}$ for the $1985-2014$ period. Hence, the years surveyed represent near-average conditions for temperature.

A continuous recording of chlorophyll fluorescence showed good agreement with the quantity of extracted $\mathrm{Chl}$ $a$ determined by HPLC ( $r^{2}=0.64$ for 2010 and 0.65 for 2011). The number of same-day match-ups between in situ Chl $a$ and satellite-derived Chl $a$ was low for both years, but a comparison of 8-day averaged surface Chl $a$ from MERIS with in situ data showed an excellent qualitative agreement for both years (Fig. 2). Satellite coverage was more complete in 2011 than 2010. Time series plots and maps of the two cruises showed a number of regularly occurring features that can be observed at this time of year (labelled "A" to " $\mathrm{J}$ " in Fig. 2).

A zone of high Chl $a\left(>2 \mathrm{mg} \mathrm{m}^{-3}\right)$ was observed with all methods in the coastal waters of Belgium, The Netherlands, Germany, and Denmark. This zone extended between points "A" and "B" for the map of 2010, and points "F" and "H" for 2011. High chlorophyll values $\left(>2 \mathrm{mg} \mathrm{m}^{-3}\right)$ were observed in the outer Thames Estuary and close to the English east coast as far north as the Humber Estuary, but the English coastal zone was not as clearly demarked by high Chl $a$ as the continental coast. The continuous recording of the first 7-10 days of the IBTS thus alternated between moderate $\mathrm{Chl}$ $a\left(1\right.$ to $\left.2 \mathrm{mg} \mathrm{m}^{-3}\right)$ and high Chl $a$ as the vessel covered the southern North Sea between 51.5 and $55^{\circ} \mathrm{N}$. An exceptional bloom event with Chl $a$ of over $6 \mathrm{mg} \mathrm{m}^{-3}$ was recorded at location "G" in 2011, and was clearly visible in MERIS and MODIS images.

The central section of the North Sea between 55 and $58^{\circ} \mathrm{N}$ was covered during the second and third weeks of the IBTS. This section showed low Chl $a$ values $\left(<1 \mathrm{mg} \mathrm{m}^{-3}\right)$ across most of the zone (Fig. 2), particularly in the region north of "I", 56.5 to $58.5^{\circ} \mathrm{N}, 0$ to $3^{\circ} \mathrm{E}$, which was a large region with 
(a)

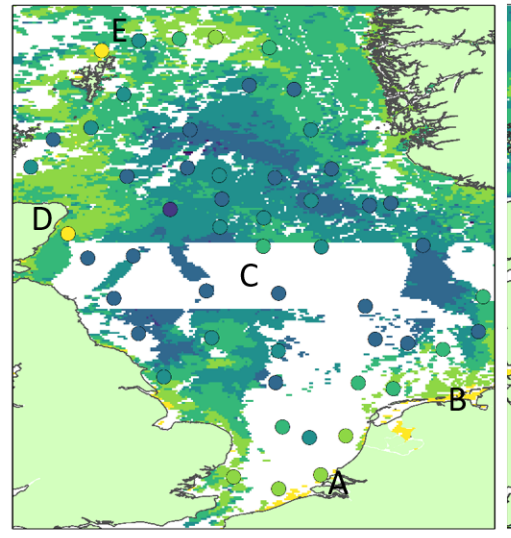

(c)

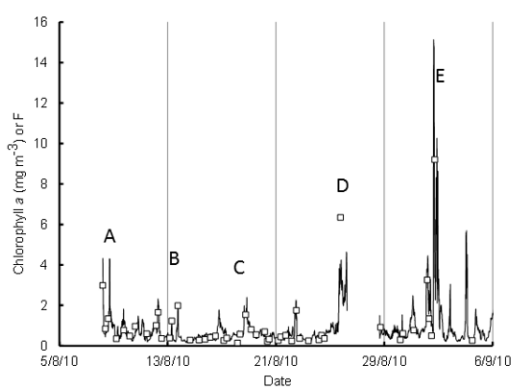

(b)

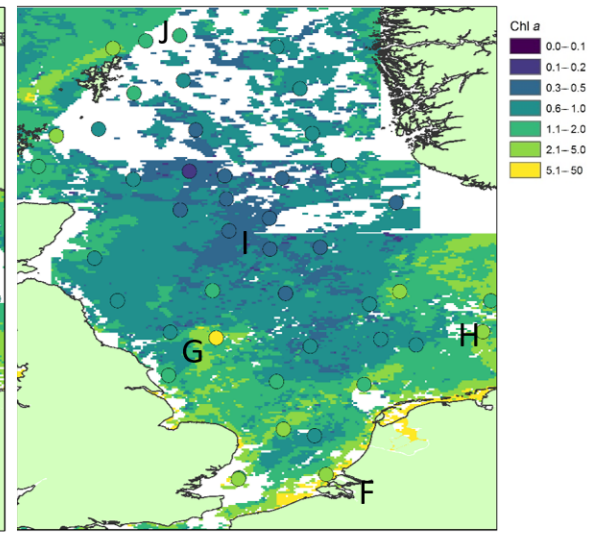

(d)

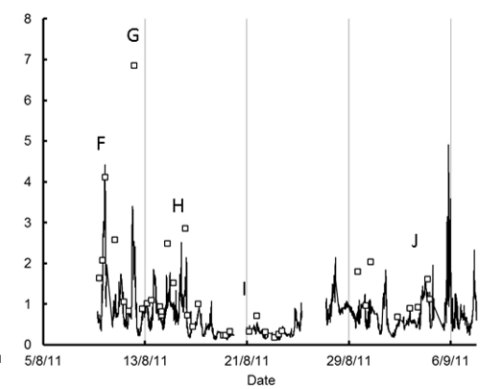

Figure 2. Maps of satellite-derived surface phytoplankton chlorophyll distribution during the summer IBTS cruises of (a) 2010 and (b) 2011 , overlaid with the in situ observations in circles. White areas are where no satellite data were available. Time series of phytoplankton chlorophyll along the IBTS cruise track in (c) 2010 and (d) 2011 as assessed by continuous measurements of chlorophyll fluorescence (solid black line), and sampling of surface water for quantification of Chl $a$ (open squares). Specific events along the tracks are referenced with a letter.

values $<0.5 \mathrm{mg} \mathrm{m}^{-3}$. To the east, the Danish coastal waters ("B" and "H") showed high Chl $a$. The inshore English coast north of the Humber, and Scottish coastal waters, are low in Chl $a$ compared to those further south. A moderate $\mathrm{Chl}$ $a$ bloom was evident in the chlorophyll fluorescence trace, MERIS image and extracted Chl $a$ at position "C" in 2010, and a high Chl $a$ patch was evident close to the Scottish coast at Aberdeen at position "D".

The northern North Sea was sampled in weeks three and four (from 28 to 29 August onwards) and was similar in 2010 and 2011. An arc of high Chl $a$ was detected from north of the Scottish mainland through the Orkneys and Shetlands, e.g. from " $D$ " to "E" in 2010 , with particularly high values at "E". In 2011, high values were observed from the Orkneys through to north of the Shetlands at "J". The FerryBox chlorophyll fluorescence recorded a further large bloom on 6 September 2011, but this event was not sampled for pigments.

As described in Sect. 2.1, PFTs were determined on the basis of accessory pigment composition. In general, pigment diversity was lower in coastal waters and in the southern North Sea and reached peak diversity in the stratified central North
Sea. Fucoxanthin was the dominant accessory marker pigment in the southern North Sea, and 19-hex was dominant in the northern North Sea. Pico-phytoplankton were represented in this analysis by the marker pigments zeaxanthin, Chl $b$ and 19-hex; these pigments were rare in the southern North Sea below a line from East Anglia to the Wadden Sea, and hence pico-phytoplankton contribution was estimated in this region to be less than $10 \%$ of total phytoplankton biomass (Fig. 3). The contribution of pico-phytoplankton increased with increasing latitude so that the area with highest contribution from the smallest PFT was found in both years to be located north of $57^{\circ} \mathrm{N}$ and east of $0^{\circ} \mathrm{E}$. Nanophytoplankton were represented by the pigments 19-hex, 19but, alloxanthin, and $\mathrm{Chl} b$. The highest percentage contribution of nano-phytoplankton was found in both years to be located in the central and northern North Sea, including the high Chl $a$ regions around the Shetland and Orkney islands. The largest PFT, micro-phytoplankton, were represented by the pigments fucoxanthin and peridinin. The distribution of this group showed highest abundance in the southern North Sea high Chl $a$ regions near the continental coast, but also in location "G" (2011) and between "C" and " $D$ " in 2010. 


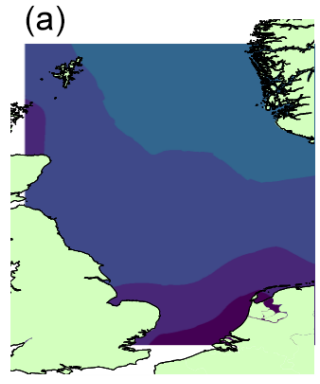

(d)

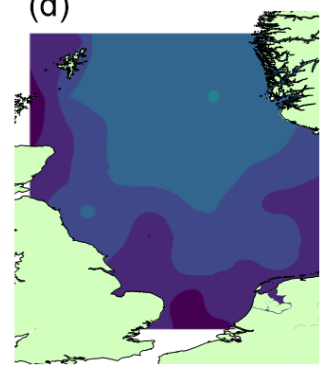

(b)

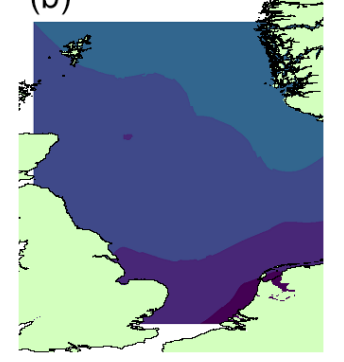

(e)

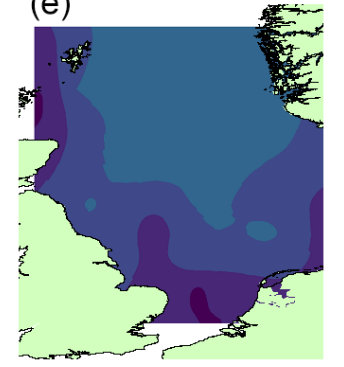

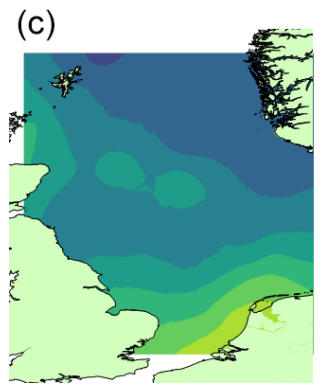

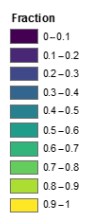

Figure 3. Maps of percentage surface PFT distribution during the summer IBTS cruises of 2010 (upper maps, a-c) and 2011 (lower maps, d-f) for pico-phytoplankton (a, d), nano-phytoplankton $(\mathbf{b}, \mathbf{e})$ and micro-phytoplankton $(\mathbf{c}, \mathbf{f})$.

The combination of continuous underway logging with autonomous instruments, high-precision pigment measurements at selected stations, and good satellite Earth observation coverage allowed the patterns of surface phytoplankton biomass and PFT distribution in the North Sea to be well understood. Together, this provided a solid observational base with which to test biogeochemical model accuracy.

\subsection{Model validation - domain scale}

This section presents validation of physical and biogeochemical model variables against a range of observation-based products, in order to assess the models' skill at broader scales than the IBTS observations measured. Detailed validation of phytoplankton community structure against the IBTS observations follows in Sect. 4.3. Since the focus of this study is on the phytoplankton community structure in August 2010 and 2011, most of the validation presented here is for these 2 months. For more general model validation the reader is referred to Edwards et al. (2012) and Wakelin et al. (2015b) for NEMO-ERSEM, and Lenhart et al. (2010), Aldridge et al. (2012), van Leeuwen et al. (2013), van der Molen et al. (2013), and van der Molen et al. (2016, 2017) for GETMERSEM-BFM in various configurations. However, some statistical assessment has been performed here for SST, chlorophyll, and SPM over the period March 2010 to October 2011. Two seasons have been defined for this assessment: the growing season and winter. The growing season is defined as March to October, and is averaged over 2010 and 2011. Winter is defined as November 2010 to February 2011. Statistics have been calculated in observation space by performing a bilinear interpolation of the daily mean model fields to the observation locations. Calculations have been performed for $\log _{10}$ (chlorophyll) rather than for chlorophyll in order to provide a more Gaussian distribution (Campbell, 1995).

Taylor plots (Taylor, 2001) of SST, $\log _{10}$ (chlorophyll), and SPM are shown in Fig. 4. SST is a good match for the observations in both the growing season and in winter, although lower correlations are found for both models in August 2010 and 2011 than for the whole seasons. Slightly better statistics are obtained for NEMO-ERSEM than for GETM-ERSEMBFM, reflecting the assimilation of SST data into NEMOERSEM. The statistics for $\log _{10}$ (chlorophyll) differ more between models and between seasons, and the models are not as good a match for the observations than with SST, as is common in physical-biogeochemical models. With SPM, the two models show large differences in variability. GETMERSEM-BFM has a much higher standard deviation than the observations in both seasons, especially the growing season, whilst the standard deviation of NEMO-ERSEM is too low all year round.

Maps of mean SST for August 2010 and 2011, the months during which most of the IBTS observations were collected, are plotted in Fig. 5, from GETM-ERSEM-BFM, NEMOERSEM, and OSTIA. There is a great deal of similarity between NEMO-ERSEM and OSTIA, which is unsurprising since NEMO-ERSEM assimilates SST data, but both NEMO-ERSEM and GETM-ERSEM-BFM are able to simulate the spatial features seen in OSTIA, as well as the interannual variability between 2010 and 2011. Boundary effects can be seen in GETM-ERSEM-BFM, which has a smaller domain. 


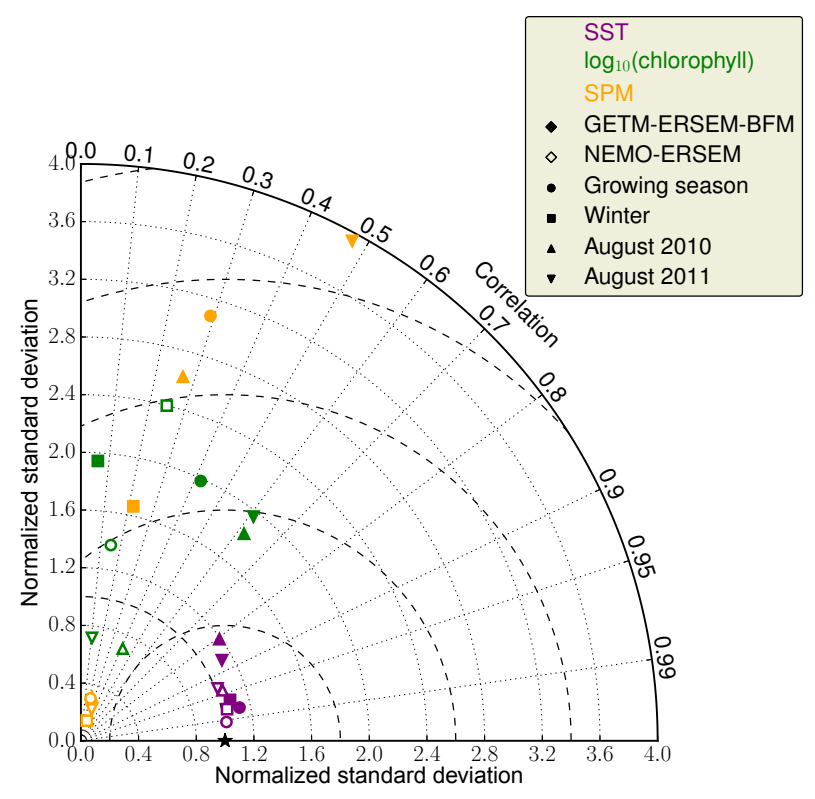

Figure 4. Taylor plot of SST (purple), $\log _{10}$ (chlorophyll) (green), and SPM (orange) for the growing season (circles), winter (squares), August 2010 (upwards triangles), and August 2011 (downwards triangles). Filled symbols are GETM-ERSEM-BFM, unfilled symbols are NEMO-ERSEM. Validation has been performed in observation space, validating the models against OSTIA for SST, and OC5 ocean colour data for $\log _{10}$ (chlorophyll) and SPM. A perfect model would plot at 1.0 on the $x$ axis, marked with a black star.

Maps of mean sea surface salinity (SSS) for August 2010 from GETM-ERSEM-BFM and NEMO-ERSEM are plotted in Fig. 6. Overlaid in circles are the in situ SSS observations from the 2010 IBTS cruise. Both models show a good qualitative match for the observations in most regions. The only area which differs substantially between the models is the Norwegian Trench and surrounding area in the northeast North Sea. In GETM-ERSEM-BFM the Norwegian coastal current disperses erroneously, spreading freshwater into the North Sea. This is not seen in the observations, and is an issue of model resolution: finer-resolution configurations of GETM do not suffer from this. The coarseness of the resolution also accounts for the Rhine freshwater plume being wider than observed.

Maps for sea surface chlorophyll concentration are plotted in Fig. 7, from the two models and the OC5 products. Daily ocean colour coverage is incomplete due to cloud cover, so the observations plotted here are simply a composite of all observations available during the month, rather than a true monthly mean. To ensure a fair comparison, the daily mean model fields were bilinearly interpolated to observation locations, and equivalent composites plotted rather than the true model mean. Van der Molen et al. (2017) presented a comparison of sub-sampled model results, accounting for cloud cover, of SPM with the true model mean, which suggested

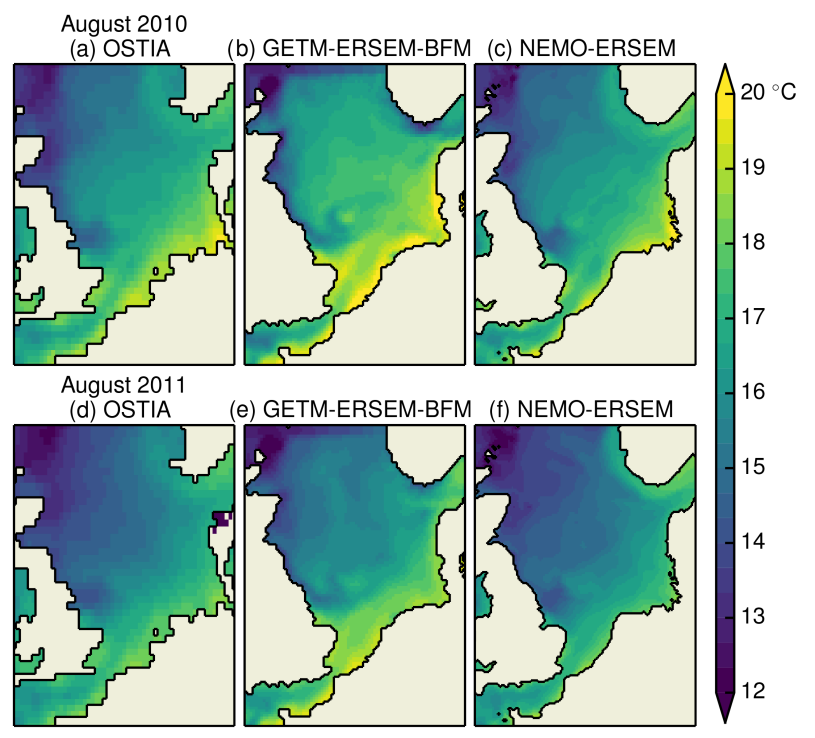

Figure 5. Maps of monthly mean SST for August 2010 (a-c) and August 2011 (d-f): observational data (a, d), GETM-ERSEM$\operatorname{BFM}(\mathbf{b}, \mathbf{e})$, and NEMO-ERSEM (c, f).

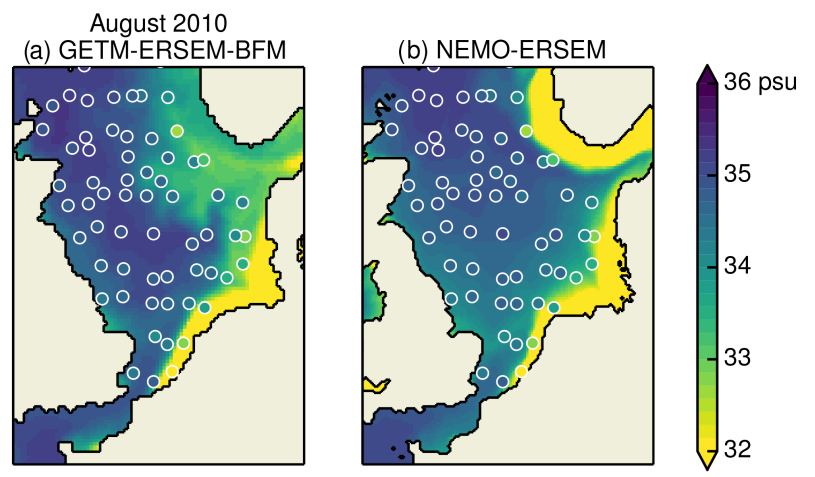

Figure 6. Maps of monthly mean SSS for August 2010 from (a) GETM-ERSEM-BFM and (b) NEMO-ERSEM. The in situ IBTS observations from August 2010 are overlaid in circles.

noticeable differences in winter, but only small differences in summer. The match between the models and the observations is not as good for chlorophyll as for SST, but both models were still able to capture some of the observed features. In the central and northern North Sea, which has the lowest chlorophyll concentrations, values were generally under-estimated by GETM-ERSEM-BFM and over-estimated by NEMOERSEM. High coastal chlorophyll values were better simulated by GETM-ERSEM-BFM, whilst the Norwegian Trench is better represented by NEMO-ERSEM. GETM-ERSEMBFM has more spatial variability than NEMO-ERSEM, despite having a lower model resolution. As with SST, there is notable inter-annual variability in the observations, with higher chlorophyll concentrations in 2011 than 2010. Both models captured this variability, although it is less evident 


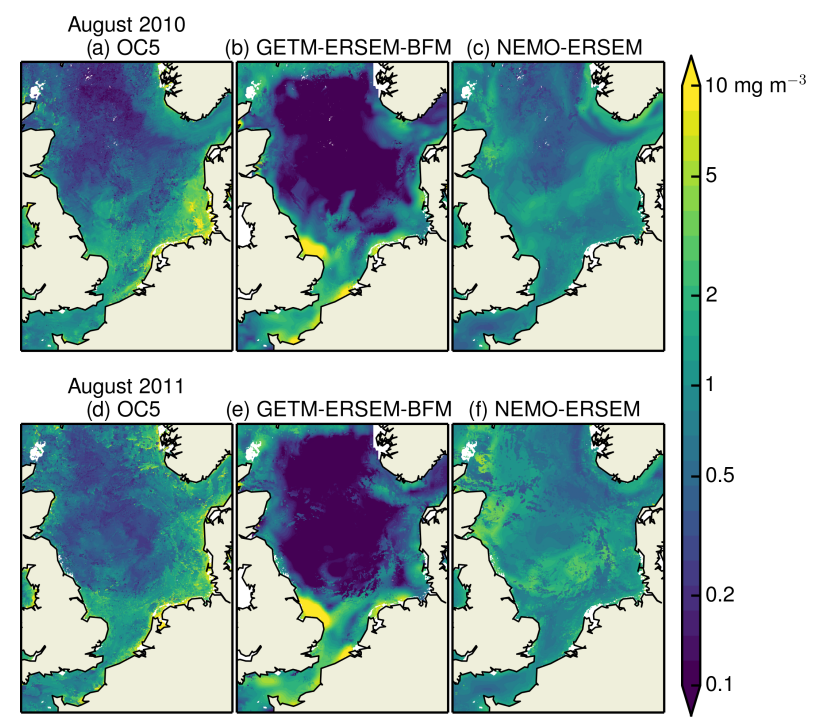

Figure 7. Composites of sea surface chlorophyll at ocean colour observation points for August 2010 (a-c) and August 2011 (df): satellite observations (a, d), GETM-ERSEM-BFM (b, e), and NEMO-ERSEM (c, f).

in GETM-ERSEM-BFM, and over-pronounced in NEMOERSEM.

The models are similarly compared to the OC5 SPM products in Fig. 8. NEMO-ERSEM and GETM-ERSEM-BFM both under-estimate SPM in the central and northern North Sea, with NEMO-ERSEM also under-representing the plume of SPM off southeast England. Overall, the two models give very different results for SPM, and the reasons for and potential consequences of this are discussed in Sect. 5.

Maps of mean surface nitrate, phosphate, and silicate for each model for August 2010 are shown in Fig. 9, alongside the corresponding World Ocean Atlas climatology fields. Only 2010 is plotted because very similar patterns are seen in the models for both years, and the climatologies do not include inter-annual variability. It should also be noted that the climatologies are of relatively coarse $1^{\circ}$ resolution, so provide only a basic representation of the North Sea, but are the only source of data with full spatial coverage available for such a comparison. The climatologies have been used as boundary conditions by both models, so are not strictly independent, but values within the North Sea domain have not been used as input to the models. For nitrate, the main limiting nutrient in the North Sea, GETMERSEM-BFM shows high coastal concentrations, and very low concentrations elsewhere. NEMO-ERSEM has a similar pattern, but with a much less extreme range of values. Likewise for phosphate and silicate, NEMO-ERSEM and GETMERSEM-BFM show differing distributions to each other, and match some of the climatological features but not others. Overlaid on the maps are in situ surface nutrient observations sampled on the 2010 IBTS cruise. These show near-

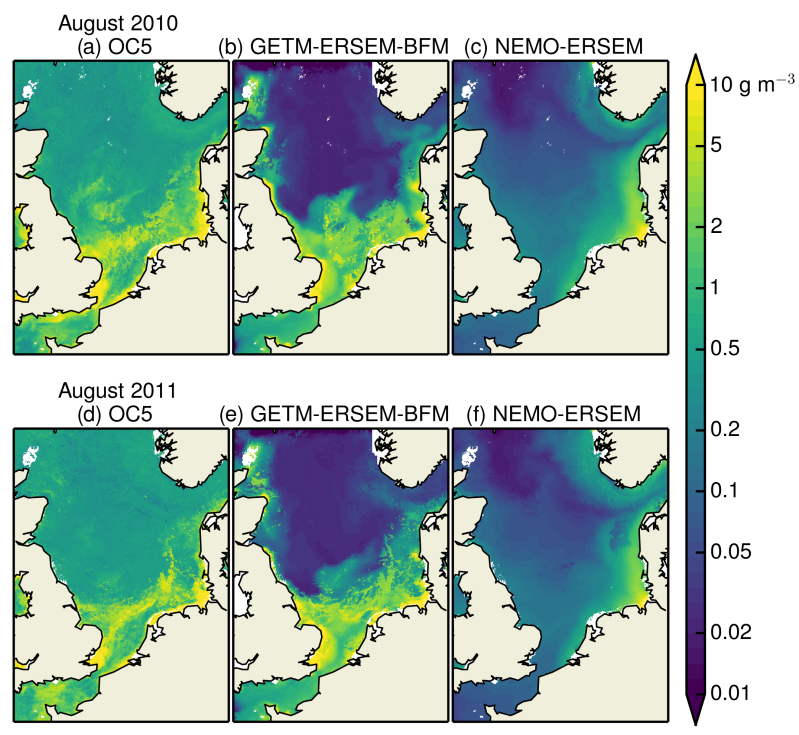

Figure 8. Composites of sea surface SPM at ocean colour observation points for August 2010 (a-c) and August 2011 (d-f): satellite observations (a, d), GETM-ERSEM-BFM (b, e), and NEMO$\operatorname{ERSEM~(c,~f).~}$

depletion of nitrate and phosphate across most of the North Sea. The depletion of nitrate is captured well by GETMERSEM-BFM, but is not seen to the same extent in either NEMO-ERSEM or the climatological World Ocean Atlas fields. The in situ observations also show greater depletion of phosphate than either of the models or the climatology, but the models are a better match for the silicate observations.

\subsection{Model validation against PFT observations}

This section presents validation of the models against the chlorophyll and PFT observations collected on the IBTS cruises. Hereafter, Micro is used to refer to the fraction of total chlorophyll represented by the micro-phytoplankton size class, and similarly Nano and Pico. Model PFTs were aggregated as described in Sect. 3.4. The most northerly of the IBTS observations were located outside the GETM-ERSEMBFM model domain; these have been excluded from the assessment to ensure the same observations were used to validate both models.

Maps of mean surface model PFTs for August 2010, as fractions of total chlorophyll, are plotted in Fig. 10. These show very different distributions for NEMO-ERSEM and GETM-ERSEM-BFM, much more so than the difference in total chlorophyll might suggest. In particular, NEMOERSEM shows dominance by pico-phytoplankton in the southern North Sea, similar fractions of pico-phytoplankton and flagellates in the rest of the domain, and generally low concentrations of diatoms and dinoflagellates. In contrast, GETM-ERSEM-BFM shows dominance by diatoms in coastal regions, and by pico-phytoplankton in the centre of 
Table 3. Statistical comparison of $\log _{10}$ (chlorophyll) and phytoplankton size classes against IBTS observations.

\begin{tabular}{|c|c|c|c|c|c|c|}
\hline Year & Model & Variable & Bias & RMSE & Correlation & No. observations \\
\hline \multirow[t]{8}{*}{2010} & \multirow[t]{4}{*}{ GETM-ERSEM-BFM } & $\log _{10}($ chlorophyll $)\left(\log _{10}\left(\mathrm{mg} \mathrm{m}^{-3}\right)\right)$ & 0.369 & 0.597 & 0.334 & \multirow[t]{8}{*}{46} \\
\hline & & Micro (fraction) & 0.069 & 0.285 & 0.010 & \\
\hline & & Nano (fraction) & -0.006 & 0.170 & 0.116 & \\
\hline & & Pico (fraction) & -0.062 & 0.182 & -0.265 & \\
\hline & \multirow[t]{4}{*}{ NEMO-ERSEM } & $\log _{10}($ chlorophyll $)\left(\log _{10}\left(\mathrm{mg} \mathrm{m}^{-3}\right)\right)$ & 0.017 & 0.339 & 0.446 & \\
\hline & & Micro (fraction) & -0.385 & 0.434 & 0.160 & \\
\hline & & Nano (fraction) & 0.146 & 0.165 & 0.604 & \\
\hline & & Pico (fraction) & 0.240 & 0.292 & -0.369 & \\
\hline \multirow[t]{8}{*}{2011} & \multirow[t]{4}{*}{ GETM-ERSEM-BFM } & $\log _{10}($ chlorophyll $)\left(\log _{10}\left(\mathrm{mg} \mathrm{m}^{-3}\right)\right)$ & 0.178 & 0.543 & 0.343 & \multirow[t]{8}{*}{39} \\
\hline & & Micro (fraction) & 0.138 & 0.261 & 0.265 & \\
\hline & & Nano (fraction) & -0.076 & 0.134 & 0.387 & \\
\hline & & Pico (fraction) & -0.062 & 0.178 & -0.061 & \\
\hline & \multirow[t]{4}{*}{ NEMO-ERSEM } & $\log _{10}($ chlorophyll $)\left(\log _{10}\left(\mathrm{mg} \mathrm{m}^{-3}\right)\right)$ & 0.067 & 0.389 & 0.157 & \\
\hline & & Micro (fraction) & -0.270 & 0.382 & -0.416 & \\
\hline & & Nano (fraction) & 0.063 & 0.121 & 0.359 & \\
\hline & & Pico (fraction) & 0.207 & 0.299 & -0.530 & \\
\hline \multirow[t]{8}{*}{$2010+2011$} & \multirow[t]{4}{*}{ GETM-ERSEM-BFM } & $\log _{10}($ chlorophyll $)\left(\log _{10}\left(\mathrm{mg} \mathrm{m}^{-3}\right)\right)$ & 0.282 & 0.573 & 0.320 & \multirow[t]{8}{*}{85} \\
\hline & & Micro (fraction) & 0.101 & 0.274 & 0.097 & \\
\hline & & Nano (fraction) & -0.039 & 0.154 & 0.178 & \\
\hline & & Pico (fraction) & -0.062 & 0.180 & -0.163 & \\
\hline & \multirow[t]{4}{*}{ NEMO-ERSEM } & $\log _{10}($ chlorophyll $)\left(\log _{10}\left(\mathrm{mg} \mathrm{m}^{-3}\right)\right)$ & 0.040 & 0.363 & 0.358 & \\
\hline & & Micro (fraction) & -0.332 & 0.411 & -0.210 & \\
\hline & & Nano (fraction) & 0.108 & 0.146 & 0.401 & \\
\hline & & Pico (fraction) & 0.225 & 0.295 & -0.452 & \\
\hline
\end{tabular}

the domain, with generally lower fractions of the remaining PFTs. The two PFTs unique to GETM-ERSEM-BFM, resuspended benthic diatoms and Phaeocystis colonies, only show notable concentrations in certain coastal areas. The reasons for the differences between the two models are discussed in Sect. 5 .

The bias, root mean square error (RMSE), and correlation of modelled versus observed total chlorophyll concentration are shown in Table 3. GETM-ERSEM-BFM has a slight bias towards too-high chlorophyll, whilst the bias for NEMOERSEM is near-zero. GETM-ERSEM-BFM chlorophyll values are typically higher than those from NEMO-ERSEM, but also show a greater range. These features are consistent between the two years. However, whilst GETM-ERSEM-BFM has a similar correlation value for both years, the correlation for NEMO-ERSEM is much higher in 2010 than 2011. It should be noted though that these statistics are based on a relatively small number of points, so any conclusions drawn from this comparison are not guaranteed to be robust, particularly given the domain-scale spatial variability (see Sect. 4.2 and Fig. 7).

A comparison of phytoplankton community structure in the models and IBTS observations has been made by aggregating the model PFTs into the three observed PSCs, as de- scribed in Sect. 3.4. The bias, RMSE, and correlation of the modelled versus observed total PSCs are shown in Table 3. Bias and RMSE are generally lower for GETM-ERSEMBFM than for NEMO-ERSEM, particularly for Micro and Pico. NEMO-ERSEM has higher absolute correlations, but for Micro and Pico these tend to be negative, suggesting that NEMO-ERSEM is getting Nano approximately correct, but Micro and Pico are inversely distributed compared with the observations.

The distribution of relative PSC fractions with total chlorophyll is plotted for each data set in Fig. 11. Consistent with results from previous studies (e.g. Devred et al., 2011), as observed chlorophyll increases, Micro tends to increase, and Nano and Pico decrease. This pattern is also seen to some extent in GETM-ERSEM-BFM, but less so in NEMO-ERSEM (and only in 2010), although NEMO-ERSEM has a smaller range of chlorophyll concentrations. In the IBTS data there is a clear overall dominance of Micro. This is well reproduced by GETM-ERSEM-BFM, but the opposite is found in NEMO-ERSEM. The exception to this is a group of observations at low chlorophyll concentrations, most notably in 2011, in which Micro is least abundant, better matching typical NEMO-ERSEM results. These observations were all 


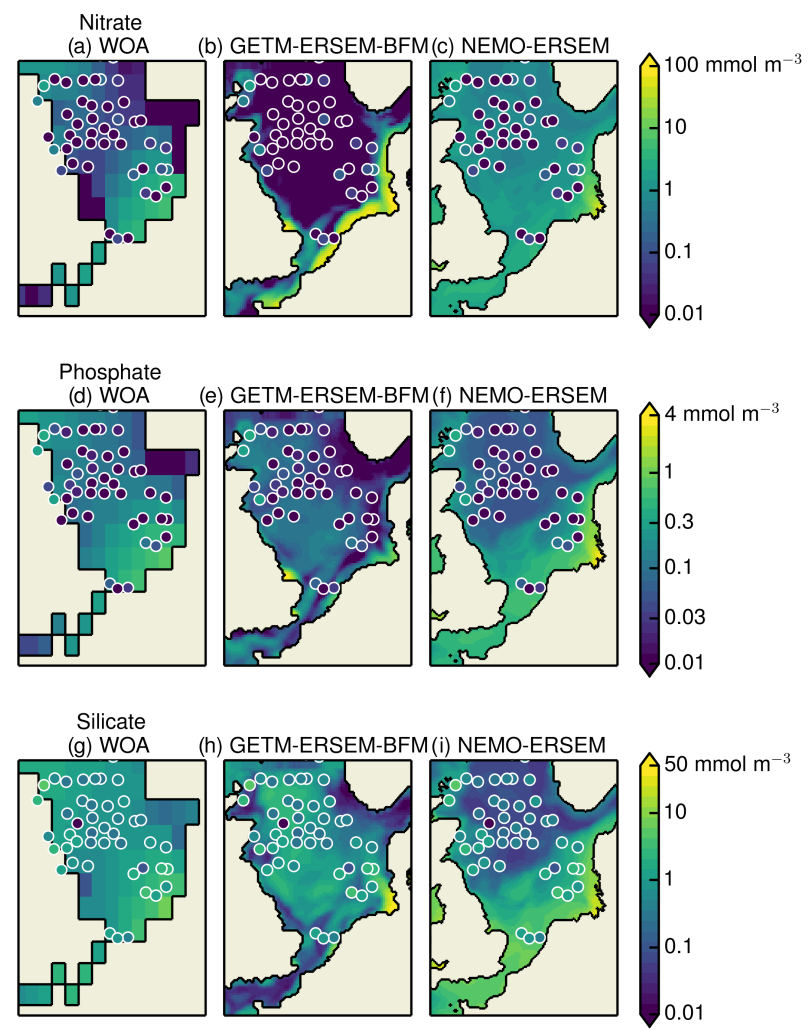

Figure 9. Maps of monthly mean sea surface nitrate (a-c), phosphate (d-f), and silicate (g-i) for August 2010: World Ocean Atlas climatology (a, d, g), GETM-ERSEM-BFM (b, e, h), and NEMOERSEM $(\mathbf{c}, \mathbf{f}, \mathbf{i})$. The in situ IBTS surface observations from August 2010 are overlaid in circles.

taken in the central North Sea, and this behaviour is discussed further in Sect. 5.

To explore the model behaviour further, and allow comparison with other works such as de Mora et al. (2016), histograms of the distribution of relative PSC fractions with total chlorophyll are plotted in Fig. 12, from each model grid point in the North Sea. These have used the mean model fields for August 2010 and August 2011. With this extended number of model points, a clear relationship is seen for GETM-ERSEM-BFM, with Micro increasing with total chlorophyll, and Pico decreasing. This matches the trend seen in the IBTS observations, as well as previous studies (e.g. Brewin et al., 2010; Devred et al., 2011). For NEMOERSEM, the range of chlorophyll concentrations remains small, making any relationship difficult to assess. When there are higher chlorophyll values a similar pattern of increasing Micro and decreasing Pico is seen, but there are too few points to draw a robust conclusion on the model relationship.

Three variables which always sum to one can be displayed in a single space, barycentric coordinates, using a ternary plot (e.g. Jupp et al., 2012). Phytoplankton community structure is plotted this way in Fig. 13. The observations form a distinct line in this space, from the centre of the plot to the corner

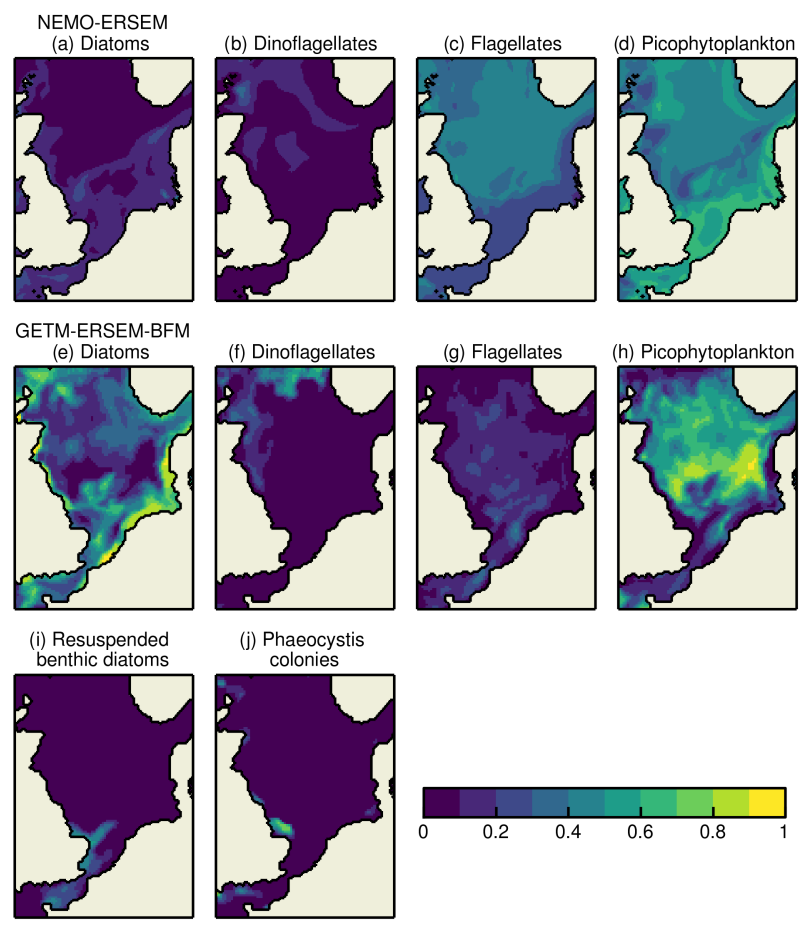

Figure 10. Maps of monthly mean sea surface PFT fractions for August 2010 from NEMO-ERSEM (a-d) and GETM-ERSEMBFM (e-j). PFT fractions have been calculated as the proportion of the total sea surface chlorophyll concentration.

representing dominance by Micro. At lower chlorophyll concentrations (not shown in Fig. 13, but consistent with Fig. 11) there are roughly equal fractions of Micro, Nano, and Pico. As chlorophyll concentration increases, Nano and Pico decrease in roughly equal amounts, with Micro increasing accordingly. The fact that the observations form a line in this space shows Nano and Pico to change in roughly equal proportions when Micro changes with chlorophyll, which differs to some extent from other studies such as Brewin et al. (2010). GETM-ERSEM-BFM displays a similar pattern, with values in the same area of the plot as the observations, although with a less distinct relationship. NEMO-ERSEM values show a very different distribution however. There is some overlap with the observations in 2011 , but otherwise a much less Micro-dominated regime is evident.

The ternary plot can also be used as a colour key to produce a map of phytoplankton community structure, as in Fig. 14. This plots the August mean community structure for each model and each year, overlaid with the IBTS point observations in circles. Plotting the community structure in such a fashion demonstrates that whilst GETM-ERSEMBFM and NEMO-ERSEM give very different results in terms of the magnitudes of the PSC fractions, there are nonetheless some broadly consistent features in terms of spatial patterns, which are also evident to some extent in the observations. For instance, both models (although NEMO-ERSEM less so in 

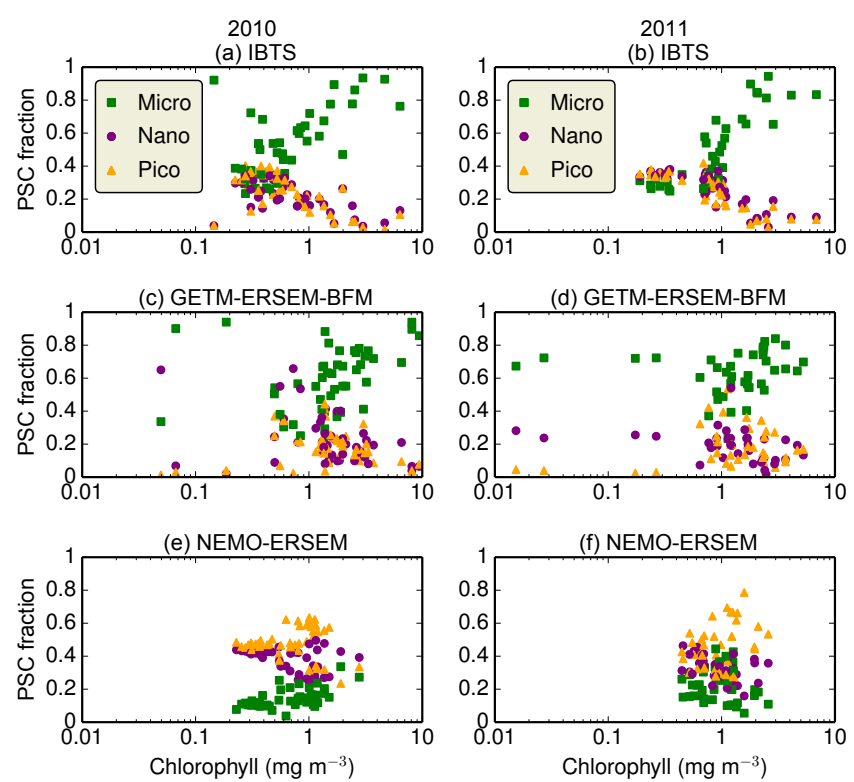

Figure 11. Phytoplankton size class (PSC) distribution as a function of chlorophyll concentration, plotted at each IBTS observation location in 2010 (a, c, e) and 2011 (b, d, f) from the IBTS observations (a, b), GETM-ERSEM-BFM (c, d), and NEMO-ERSEM (e, f).

2010) show a distinct split in community structure between the southern and northern North Sea, and around bathymetric features such as Dogger Bank and coastlines. Such a split can be clearly seen in the 2011 observations, which show very little variation throughout the central North Sea, but is less clear in the 2010 observations. A difference between the years in the community structure in the central North Sea is also seen in NEMO-ERSEM, and to a lesser extent GETMERSEM-BFM, although the direction of change in the models is from Pico-dominated to Micro-dominated, the opposite of that in the observations. Although in most cases the community structure in the models does not match that of the observations, GETM-ERSEM-BFM is a very good match for the observations in the southern North Sea, an area particularly dominated by diatoms in the model. Silicate in this region is near-depleted in GETM-ERSEM-BFM (see Fig. 9), but abundant in NEMO-ERSEM. In GETM-ERSEM-BFM, distinct blue patches can be seen off East Anglia, South Dorset, and the German Bight, which are mostly areas where Phaeocystis colonies dominate in the model.

\section{Summary and discussion}

This study has presented a new set of in situ phytoplankton pigment observations for the North Sea, processed to give information on phytoplankton community structure. Two physical-biogeochemical models, the biogeochemical components of which are different variants of ERSEM, were then
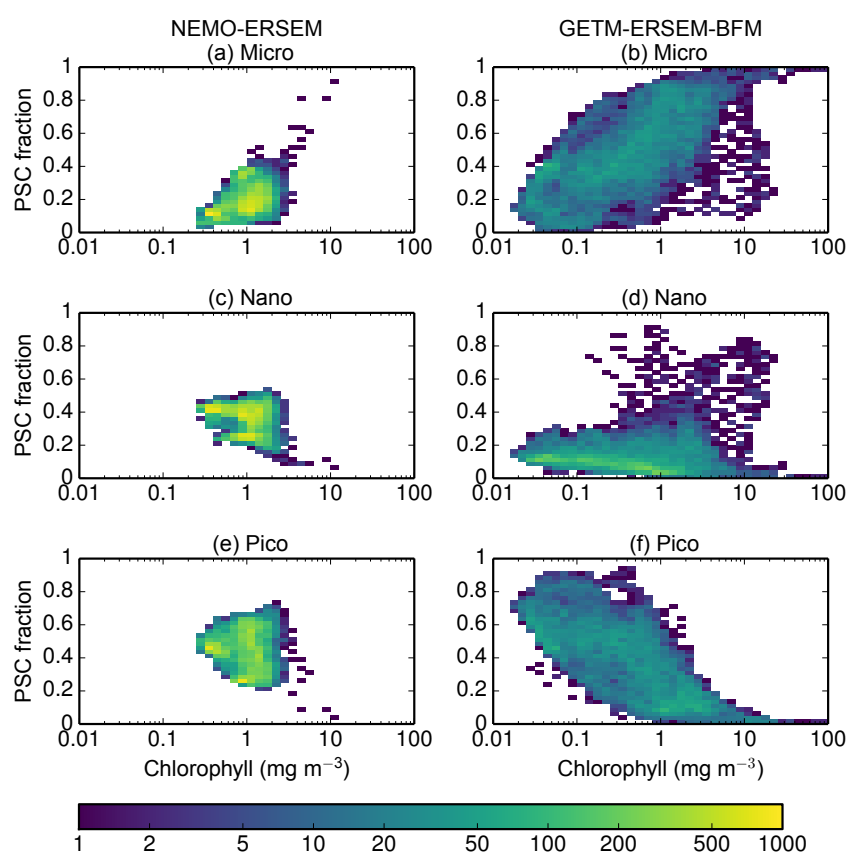

Figure 12. 2-D histograms of the distribution of each phytoplankton size class (PSC) with chlorophyll, from NEMO-ERSEM (a, c, e) and GETM-ERSEM-BFM (b, d, f). The PSC fractions have been calculated at each surface model grid point in the monthly means for August 2010 and August 2011. Colours represent the number of occurrences per bin.

validated against these and other observations. Both models were a good match for SST observations, and a reasonable match for chlorophyll observations, but gave contrasting results for SPM. Furthermore, the two models displayed very different phytoplankton community structures. GETM-ERSEM-BFM was able to reproduce many of the features of the observations, particularly in the southern North Sea, whereas NEMO-ERSEM was a poor match for the observations, except at the lowest chlorophyll concentrations. Nonetheless, both models shared some similarities with each other and the observations in terms of spatial features and inter-annual variability.

The distribution of total phytoplankton biomass across the North Sea during summer of both years showed a high degree of consistency between three different observational methods: satellite remote sensing, high-frequency continuous measurement of chlorophyll fluorescence, and Chl $a$ quantification at discrete stations. A similar set of spatial features can be observed in 2010 and 2011, which can be explained by the underlying hydrodynamics (van Leeuwen et al., 2015). The central, strongly stratified region of the North Sea has very low nutrient concentrations and correspondingly low Chl $a$. In areas where vertical mixing, riverine input, or horizontal advection bring nutrients into the upper water column, phytoplankton biomass is elevated. As well as observing the total quantity of phytoplankton, de- 

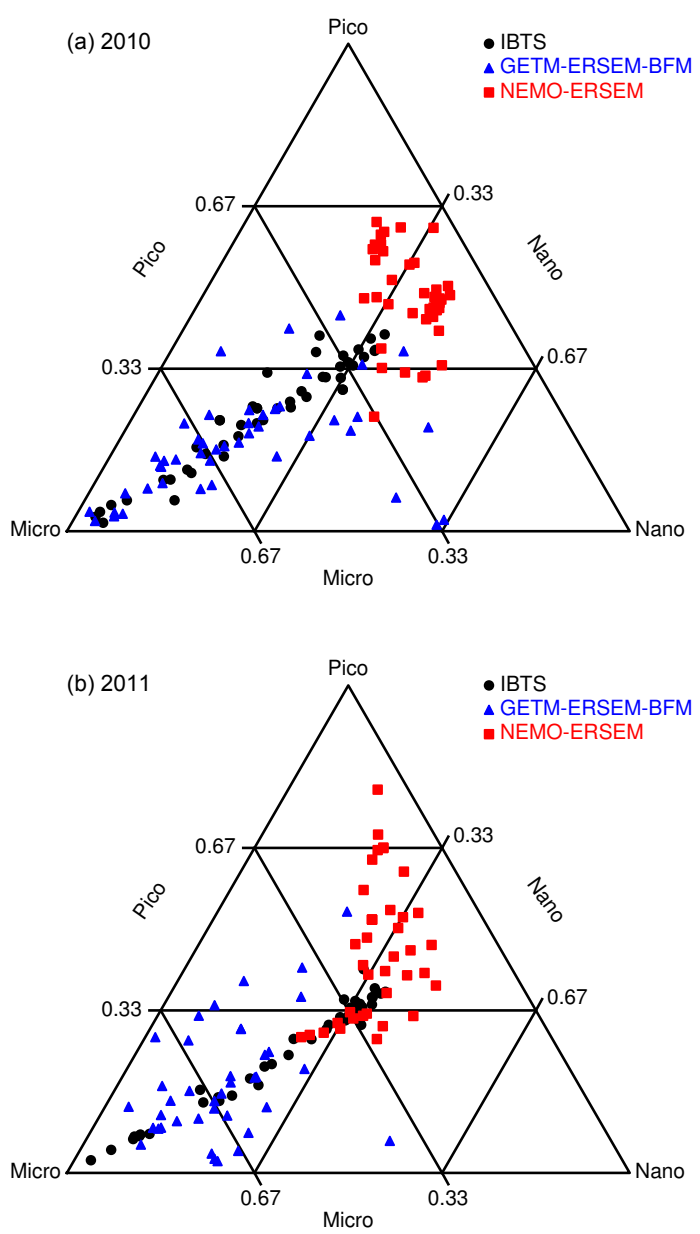

Figure 13. Ternary plots of phytoplankton community structure, showing the phytoplankton size class distribution at IBTS observation locations in (a) 2010 and (b) 2011, from the IBTS observations, GETM-ERSEM-BFM, and NEMO-ERSEM.

riving the composition of size and functional types is important for a better understanding of ecosystem function and energy flows to higher trophic levels (Chavez et al., 2011). Accessory pigments have been widely used in biological oceanography to investigate community composition, but caution must be applied when interpreting results, and support from other methods should be used where possible (Schlüter et al., 2014). The original equations used by Hirata et al. $(2008,2011)$ to convert pigments to pico-, nano-, and micro-phytoplankton size classes underestimated the fraction of pico-phytoplankton compared to flow cytometric observations, and were modified by increasing the contribution of $\mathrm{Chl} b$ and 19-hex to this class. Results in both years showed a consistent pattern of decreasing micro-phytoplankton abundance with distance from the coast, and with increasing latitude, and this is supported by previous pigment-based studies. Work in the German Bight has also shown a change from a coastal, diatom-dominated community to a more diverse,

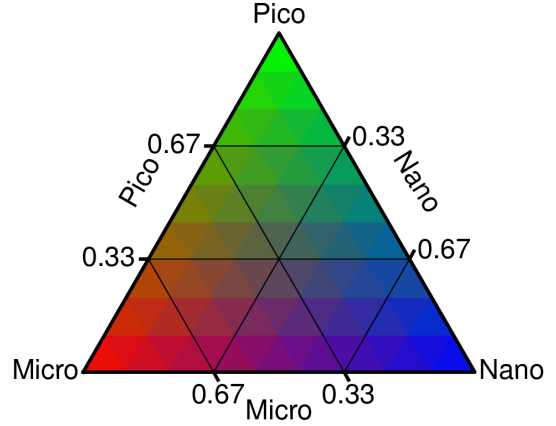

August 2010

(a) NEMO-ERSEM

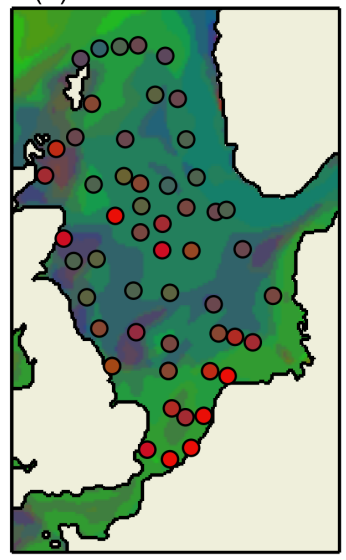

August 2011

(c) NEMO-ERSEM

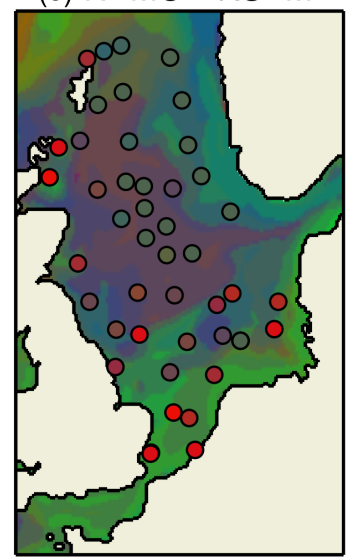

(b) GETM-ERSEM-BFM

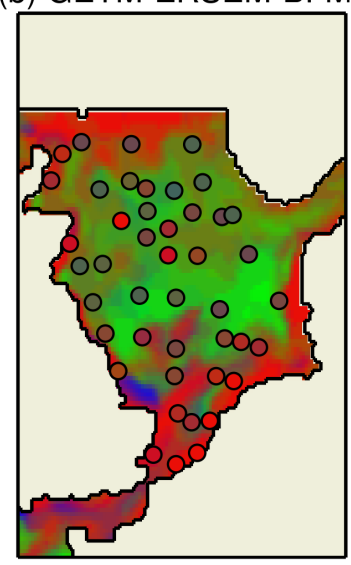

(d) GETM-ERSEM-BFM

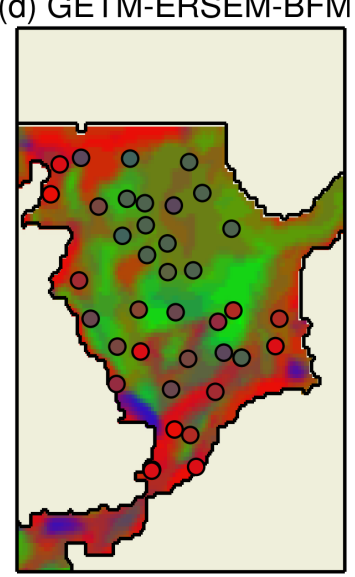

Figure 14. Maps of modelled surface phytoplankton community structure for August 2010 (a, b) and August 2011 (c, d) from NEMO-ERSEM $(\mathbf{a}, \mathbf{c})$ and GETM-ERSEM-BFM $(\mathbf{b}, \mathbf{d})$. The IBTS observations, sampled in August and early September of each year, are overlaid in circles.

small-celled community further offshore (Brandsma et al., 2013; Wollschläger et al., 2015).

Both NEMO-ERSEM and GETM-ERSEM-BFM have shown the ability to reproduce the physics and broad-scale biogeochemistry of the North Sea. However, results are more 
varied when considering specific aspects such as the phytoplankton community structure in August. In some ways this is to be expected, as this study has used existing model versions which have not been previously validated against or tuned to such observations. Furthermore, August is a challenging month to model in the North Sea, as evidenced by the reduced SST skill for this month compared with the seasonal average. This is because simulating the details of the stratification, nutrient concentrations and therefore phytoplankton concentrations is dependent on having successfully simulated processes in previous months, as well as the processes seen during August. This is more important than at other times of year, because, being at the height of summer, there are no strong temporal gradients driving the response of the system, as in spring and autumn. As a result, the internal biogeochemical dynamics can play out most freely (both in reality and in the model). Nonetheless, this kind of specific information is in increasing demand, and if results are to be provided to users then they should be understood and validated.

NEMO-ERSEM and GETM-ERSEM-BFM gave very different representations of SPM concentrations, which impacts ecosystem functioning through light limitation (see also the light susceptibility parameters, Table 2). NEMOERSEM uses the two-size class SPM model described by Sykes and Barciela (2012). This was implemented by Sykes and Barciela (2012) in the POLCOMS (Proudman Oceanographic Laboratory Coastal Ocean Modelling System; Holt and James, 2001; Holt et al., 2005) physical framework, in which it gave skilful results compared with observations. However, the model has not yet received the same degree of tuning and development since being implemented in NEMO-ERSEM, which may explain the consistent underestimation of SPM found in this study. Furthermore, the high vertical resolution of NEMO-ERSEM means that the settling velocities must sometimes be artificially limited when used by the SPM model, in order to avoid breaking the Courant-Friedrichs-Lewy (CFL) condition (Courant et al., 1928), thus reducing resuspension. Changes to the settling parameters would be expected to lead to improvements. GETM-ERSEM-BFM uses an alternative SPM model (van der Molen et al., 2017), which only has one size class but includes resuspension by waves as well as currents, and which was developed within the GETM-ERSEM-BFM framework. This generally matches spatial distributions of SPM better, but often has concentrations which are extremely high or low compared with satellite data, leading to a degradation in some error statistics.

The starkest contrast between the model results presented in this study is in the simulated phytoplankton community structures, which differ far more than might be expected given the corresponding total chlorophyll concentrations. GETM-ERSEM-BFM gave a wider range of combinations of biomass in the three size classes resolved by the observations than NEMO-ERSEM did. This was also reflected in more spatial variability and stronger spatial gradients, which resulted in a better match of the coastal to offshore change in phytoplankton community structure evident in the observations, in which diatoms are particularly important. The limited biomass in the two additional PFTs in GETM-ERSEMBFM (benthic diatoms and Phaeocystis colonies, Fig. 10) suggests that these were not the primary cause of this difference in response. Two mechanisms are likely to play important roles in causing the differences: (1) the higher coastal nutrient concentrations in combination with the different nutrient affinity settings in GETM-ERSEM-BFM, allowing diatoms to out-compete other types, in contrast with identical nutrient affinity settings in NEMO-ERSEM; (2) the coincidence of diatoms with areas of high SPM concentrations in GETM-ERSEM-BFM (mostly absent in NEMO-ERSEM) in combination with greater light susceptibility of diatoms (again contrasting with uniform values in NEMO-ERSEM), giving them competitive advantage. Similar, but more subtle effects will modulate the response of the other PFTs in GETM-ERSEM-BFM. Overall, the more uniform parameter settings of NEMO-ERSEM promote a more uniform response of the PFTs, as is evident in the results. Further work, with dedicated experiments performed in a configuration designed for such a comparison, could be carried out to further investigate these differences, and this is discussed below.

GETM-ERSEM-BFM provided a better match for the IBTS observations of phytoplankton community structure than NEMO-ERSEM did. The exception to this was in the low-chlorophyll waters of the central North Sea, the region of the domain with the weakest currents and largest residence times. Here the community structure of the observations more closely resembled that typical of NEMOERSEM. There are indications that recent versions of NEMO-ERSEM, applied to the global ocean rather than to the Northwest European Shelf seas, perform better at reproducing observed community structures (de Mora et al., 2016). Together with the results presented here, this suggests that NEMO-ERSEM may be more representative of an open ocean environment, whereas the settings in GETM-ERSEMBFM are better suited to the complex coastal environment of the North Sea.

Whilst there were large contrasts in the corresponding ratios of PSCs between all three data sets, there was more agreement between the data sets about the spatial patterns of community structure. For instance, each had contrasting structures between the southern and central North Sea, and in coastal areas. Furthermore, inter-annual variability in the central North Sea was clearly evident in the observations, and also each of the models. This can be compared to differences in SST between the two years and the two models, suggesting a set of physical drivers which the models were able to capture. Across much of the North Sea the SST was cooler in 2011 than 2010, as seen in Fig. 5. Typical mixed layer depths were also deeper in the models in 2011 (not shown), likely in response to increased wind speeds. This deepening of the 
mixed layer cooled the SST and brought more nutrients to the surface, increasing production and chlorophyll, as seen in Fig. 7. In NEMO-ERSEM, which showed the most interannual variability in phytoplankton community structure, all PFTs increased in chlorophyll, but dinoflagellates increased the most in percentage terms, shifting the community structure more towards Micro-dominance. This could be because the changes in temperature and prey availability favoured smaller predators more than larger ones, and an increase in the ratio of nitrate to ammonium best suited larger phytoplankton. This implies that even if models are currently unable to accurately represent the exact community structures, they can still be used to assess the distribution of different habitats, and when and where these may change.

Due to differences in locations, timescales, and data sets, a robust comparison with results from other PFT modelling studies in the literature cannot be made at this stage. Nonetheless, a consideration of the types of results obtained using different modelling approaches is of value. Lewis et al. (2006) and Lewis and Allen (2009) both validated a similar version of the PML-developed ERSEM, coupled with the POLCOMS hydrodynamic model, against in situ observations of PFTs in the Northwest European Shelf. Lewis et al. (2006) validated against Continuous Plankton Recorder (CPR; Richardson et al., 2006) data, and found that whilst the model reproduced the main seasonal features of plankton succession, diatoms consistently bloomed too early, and there were some spatial differences, especially in the North Sea. This would seem consistent with the low diatoms seen in NEMO-ERSEM in August in this study. Lewis and Allen (2009) validated against a station in the Western English Channel, and found a poor match for phytoplankton variables when assessment was performed in observation space, as has been done here, but a better match when assessing more general seasonal variability. On a global openocean scale, Gregg and Casey (2007) validated the NASA Ocean Biogeochemical Model (NOBM) against both in situ and remotely sensed estimates of PFTs, with a focus on coccolithophores, and described their results as "mixed", noting contrasting results elsewhere in the literature. Hirata et al. (2013) validated the MEM-OU model against remote sensing estimates of large and small phytoplankton, and found good agreement at basin scales, but which reduced at smaller scales. De Mora et al. (2016) compared PFT distributions with chlorophyll from the most recent ERSEM version of Butenschön et al. (2016) to those obtained using various remote sensing algorithms applied to the model data, and found that the model displayed similar properties at global scales. These studies (not exhaustive) all used models with a relatively small fixed number of specifically parameterized PFTs. An alternative approach is to initialize the model with a large number of randomly parameterized PFTs, with the best-suited PFTs naturally dominating (Follows et al., 2007). In a global setting this approach has been found to successfully reproduce large-scale patterns of phytoplankton diver- sity in terms of organism size (Follows et al., 2007) and number of co-existing species (Barton et al., 2010). The ability of such a model to reproduce the short-term variability of a complex coastal environment such as the North Sea would make for an interesting future inter-comparison. In general, results in the literature suggest some success of different approaches at reproducing large-scale patterns of phytoplankton community structure, but with more detailed skill yet to be properly demonstrated.

Careful thought needs to be given therefore to what products and information can be offered to users, which address user and policy requirements with a sufficient level of skill (Hyder et al., 2015). Continual model developments will be required. A comprehensive review of the challenges faced is given by Holt et al. (2014), and results from this current study should further inform future model development. This will be particularly relevant in the context of the UK Shelf Seas Biogeochemistry (SSB) research programme (http://www.uk-ssb.org), in which Cefas and the Met Office are both participants. One of the aims of the SSB programme is to create a common version of ERSEM to be used by the UK research community, by combining features of the two versions of ERSEM used in this study. An initial combined version is described by Butenschön et al. (2016), and this will be further developed within the SSB programme. The version of Butenschön et al. (2016) provides a major update to that of Blackford et al. (2004), which forms the basis of the NEMOERSEM version used in this study, and initial applications (Butenschön et al., 2016; de Mora et al., 2016; Ciavatta et al., 2016) have shown different phytoplankton community structures to that obtained in this work. It is clear from this study that the details of the model components and parameterizations can lead to very different results, and validation against a range of data, using a range of methods, is vital throughout the model development cycle.

The assessment presented in this study suggests that the biogeochemical model parameterizations are important in controlling the phytoplankton community structure. However, due to the many differences in physical modelling environment and experimental configurations, it cannot be ruled out that differences in the physics are responsible for the differences in phytoplankton community structure, and previous studies have found these to be important. For instance, Sinha et al. (2010) coupled a single marine biogeochemical model with two different global physical ocean models, and found contrasting phytoplankton community structures due to differences in mixing. A number of further experiments could be performed to investigate the differences in PFT response between the models, and develop improvements. These can make use of the two ERSEM versions used in this study and the new SSB-ERSEM, along with NEMO, GETM, and GETM's 1-D counterpart GOTM (General Ocean Turbulence Model). SSB-ERSEM is compatible with the Framework for Aquatic Biogeochemical Models (FABM; Bruggeman and Bolding, 2014), allowing it to be coupled with ei- 
ther GOTM, GETM, or NEMO. Building on this framework could allow the different ERSEM versions to be run with identical hydrodynamics in 1-D and 3-D, and similarly allow individual ERSEM versions to be run with different hydrodynamics. This would help identify the differences in results introduced by different components of the system. Within this experimental framework, controlled differences to physical and biogeochemical model parameters could be made to investigate further. These would allow very efficient testing. However, the current field observations (quasi-synoptic spatial distribution for 1 month of the year) do not allow a fully robust model comparison. An observational time series resolving the seasonal cycle at one or more locations would be needed for this exercise. Recent developments of algorithms to derive PFTs from remotely sensed data (Nair et al., 2008; Hirata et al., 2013) could benefit all these potential strands of further work.

A further development will be the assimilation of biogeochemical data. Ocean colour data assimilation is being increasingly utilized by the reanalysis and forecasting community (Gehlen et al., 2015), and has already been successfully demonstrated for ERSEM (Ciavatta et al., 2011, 2014, 2016). A suitable ocean colour assimilation scheme for operational purposes is being developed as a collaboration between the Met Office and PML, to be implemented in the SSB ERSEM version and run operationally as part of CMEMS. This will also give the opportunity to take advantage of the advent of remote-sensing PFT/PSC products, incorporating such data into the assimilation and routine validation.

Information on the marine environment can come from three sources: in situ observations, remote-sensing data, and models. These three sources are inter-linked and all are vital; sufficient scientific understanding of the North Sea and other environments cannot be obtained if any of these three sources are removed. Models provide complete 3-D spatial and temporal coverage, can be used to simulate a range of hypotheses, and are relatively inexpensive. However, as demonstrated in this study, observations are necessary for the validation and development of models, and model data cannot be relied upon in isolation. Remote-sensing data provide considerably greater observational coverage than in situ measurements, but this coverage is still limited to the sea surface and cloud-free conditions, and empirical algorithms based on in situ data are used in the construction of remote sensing products. These satellite data must be comprehensively groundtruthed against in situ observations if they are to be used with confidence. Continuing in situ observations are therefore required to under-pin model and remote sensing data, as well as to provide unique insights into the marine environment. In turn, modelling studies can be used to help inform sampling strategies of future observing programmes, to help provide value for money without sacrificing accurate scientific understanding.

Finally, it remains to answer the question at the heart of this paper: "Can ERSEM-type models simulate phytoplank- ton community structure?" The evidence from this study suggests that ERSEM-type models have the potential to accurately simulate phytoplankton community structure, but certain model formulations and parameterizations are required to do so, and these two ERSEM versions do not reliably do so at this stage. Appropriate model development, informed by detailed validation studies, appears to be a major but achievable challenge, and will help facilitate the wider application of marine biogeochemical modelling to wide-ranging user and policy needs.

\section{Data availability}

The IBTS observations are available from the Cefas Data Hub (http://doi.org/10.14466/CefasDataHub.33). The NEMO-ERSEM model data are available through the Copernicus Marine Environment Monitoring Service (CMEMS), product NORTHWESTSHELF_REANALYSIS_BIO_004_011 (http://marine. copernicus.eu/services-portfolio/access-to-products/ ?option=com_csw\&view=details\&product_id= NORTHWESTSHELF_REANALYSIS_BIO_004_011). GETM-ERSEM-BFM model data are available on request from Johan van der Molen (johan.vandermolen@cefas.co.uk).

Competing interests. The authors declare that they have no conflict of interest.

Acknowledgements. Sampling of the North Sea was funded by the European Union project PROTOOL (EU FP7, grant no. 226880). The authors wish to thank Brian Harley and Sophie McCully and the officers and crew of RV Cefas Endeavour for their assistance during the IBTS surveys. David Ford and Rosa Barciela were funded through the Met Office Innovation Fund. David Ford, Rosa Barciela and Robert McEwan also received funding from the European Community's Seventh Framework Programme FP7/2007-2013 under grant agreement no. 283367 (MyOcean2), and from the Copernicus Marine Environment Monitoring Service. This paper is a contribution to the NERC-Defra funded Marine Ecosystems Research Programme (NERC award NE/L002981/1). Johan van der Molen and Kieran Hyder were funded through Cefas Seedcorn project DP235. The authors would like to thank O. Kerimoglu and two anonymous referees and Momme Butenschön for their comments in Biogeosciences Discussions.

Edited by: E. Marañón

Reviewed by: O. Kerimoglu and two anonymous referees

\section{References}

Aiken, J., Pradhan, Y., Barlow, R., Lavender, S., Poulton, A., Holligan, P., and Hardman-Mountford, N.: Phytoplankton pigments 
and functional types in the Atlantic Ocean: a decadal assessment, Deep-Sea Res. Pt II, 56, 899-917, 2009.

Aldridge, J., van der Molen, J., and Forster, R.: Wider ecological implications of Macroalgae cultivation, The Crown Estate, London, ISBN: 978-1-906410-38-4, 95 pp., 2012.

Allen, J. I. and Clarke, K. R.: Effects of demersal trawling on ecosystem functioning in the North Sea: a modelling study, Mar. Ecol.-Prog. Ser., 336, 63-75, 2007.

Anderson, T. R.: Plankton functional type modelling: running before we can walk?, J. Plankton Res., 27, 1073-1081, 2005.

Balmaseda M. A., Mogensen, K., and Weaver, A.: Evaluation of the ECMWF Ocean Reanalysis ORAS4, Q. J. Roy. Meteor. Soc., 139, 1132-1161, 2013.

Baretta, J. W., Ebenhöh, W., and Ruardij, P.: The European Regional Seas Ecosystem Model, a complex marine ecosystem model, Neth. J. Sea Res., 33, 233-246, 1995.

Barton, A. D., Dutkiewicz, S., Flierl, G., Bragg, J., and Follows, M. J.: Patterns of diversity in marine phytoplankton, Science, 327, 1509-1511, 2010.

Blackford, J. C., Allen, J. I., and Gilbert, F. J.: Ecosystem dynamics at six contrasting sites: a generic modelling study, J. Marine Syst., 52, 191-215, 2004.

Blauw, A. N., Los, F. J., Huisman, J, and Peperzak, L.: Nuisance foam events and Phaeocystis globosa blooms in Dutch coastal waters analyzed with fuzzy logic, J. Marine Syst., 83, 115-126, 2010.

Blockley, E. W., Martin, M. J., McLaren, A. J., Ryan, A. G., Waters, J., Lea, D. J., Mirouze, I., Peterson, K. A., Sellar, A., and Storkey, D.: Recent development of the Met Office operational ocean forecasting system: an overview and assessment of the new Global FOAM forecasts, Geosci. Model Dev., 7, 2613-2638, doi:10.5194/gmd-7-2613-2014, 2014.

Borja, A., Elliott, M., Andersen, J. H., Cardoso, A. C., Carstensen, J., Ferreira, J. G., Heiskanen, A. S., Marques, J. C., Neto, J. M., Teixeira, H., and Uusitalo, L.: Good Environmental Status of marine ecosystems: What is it and how do we know when we have attained it?, Mar. Pollut. Bull., 76, 16-27, 2013.

Boyes, S. J. and Elliott, M.: Marine legislation - The ultimate "horrendogram": International law, European directives and national implementation, Mar. Pollut. Bull., 86, 39-47, 2014.

Brandsma, J., Martínez, J. M., Slagter, H. A., Evans, C., and Brussaard, C. P.: Microbial biogeography of the North Sea during summer, Biogeochemistry, 113, 119-136, 2013.

Brewin, R. J., Sathyendranath, S., Hirata, T., Lavender, S. J., Barciela, R. M., and Hardman-Mountford, N. J.: A three-component model of phytoplankton size class for the Atlantic Ocean, Ecol. Model., 221, 1472-1483, 2010.

Brewin, R. J., Hardman-Mountford, N. J., Lavender, S. J., Raitsos, D. E., Hirata, T., Uitz, J., Devred, E., Bricaud, A., Ciotti, A., and Gentili, B.: An intercomparison of bio-optical techniques for detecting dominant phytoplankton size class from satellite remote sensing, Remote Sens. Environ., 115, 325-339, 2011.

Brito, A. C., Sá, C., Brotas, V., Brewin, R. J., Silva, T., Vitorino, J., Platt, T., and Sathyendranath, S.: Effect of phytoplankton size classes on bio-optical properties of phytoplankton in the Western Iberian coast: Application of models, Remote Sens. Environ., 156, 537-550, 2014.

Brotas, V., Brewin, R. J., Sá, C., Brito, A. C., Silva, A., Mendes, C. R., Diniz, T., Kaufmann, M., Tarran, G., Groom, S. B., and
Platt, T.: Deriving phytoplankton size classes from satellite data: Validation along a trophic gradient in the eastern Atlantic Ocean, Remote Sens. Environ., 134, 66-77, 2013.

Bruggeman, J.: Succession in plankton communities: A trait-based perspective, $\mathrm{PhD}$ thesis, Vrije Universiteit Amsterdam, 2009.

Bruggeman, J. and Bolding, K.: A general framework for aquatic biogeochemical models, Environ. Modell. Softw., 61, 249-265, 2014.

Burchard, H. and Bolding, K.: GETM: A General Estuarine Transport Model; Scientific Documentation, Tech. Rep. EUR 20253 EN, European Commission, 2002.

Butenschön, M., Clark, J., Aldridge, J. N., Allen, J. I., Artioli, Y., Blackford, J., Bruggeman, J., Cazenave, P., Ciavatta, S., Kay, S., Lessin, G., van Leeuwen, S., van der Molen, J., de Mora, L., Polimene, L., Sailley, S., Stephens, N., and Torres, R.: ERSEM 15.06: a generic model for marine biogeochemistry and the ecosystem dynamics of the lower trophic levels, Geosci. Model Dev., 9, 1293-1339, doi:10.5194/gmd-9-1293-2016, 2016.

Campbell, J. W.: The lognormal distribution as a model for biooptical variability in the sea, J. Geophys. Res.-Oceans, 100, 13237-13254, 1995.

Capuzzo, E., Stephens, D., Silva, T., Barry, J., and Forster, R. M.: Decrease in water clarity of the southern and central North Sea during the 20th century, Glob. Change Biol., 21, 2206-2214, 2015.

Chassot, E., Mélin, F., Le Pape, O., and Gascuel, D.: Bottom-up control regulates fisheries production at the scale of eco-regions in European seas, Mar. Ecol.-Prog. Ser., 343, 45-55, 2007.

Chavez, F. P., Messié, M., and Pennington, J. T.: Marine Primary Production in Relation to Climate Variability and Change, Annu. Rev. Mar. Sci., 3, 227-260, 2011.

Ciavatta, S., Torres, R., Saux-Picart, S., and Allen, J. I.: Can ocean color assimilation improve biogeochemical hindcasts in shelf seas?, J. Geophys. Res.-Oceans, 116, C12043, doi:10.1029/2011JC007219, 2011.

Ciavatta, S., Torres, R., Martinez-Vicente, V., Smyth, T., Dall'Olmo, G., Polimene, L., and Allen, J. I.: Assimilation of remotely-sensed optical properties to improve marine biogeochemistry modelling, Prog. Oceanogr., 127, 74-95, 2014.

Ciavatta, S., Kay, S., Saux-Picart, S., Butenschön, M., and Allen, J. I.: Decadal reanalysis of biogeochemical indicators and fluxes in the North West European shelf-sea ecosystem, J. Geophys. Res.Oceans, 121, 1824-1845, 2016.

Courant, R., Friedrichs, K., and Lewy, H.: Über die partiellen Differenzengleichungen der mathematischen Physik, Math. Ann., 100, 32-74, 1928.

Daan, N., Gislason, H., Pope, J. G., and Rice, J. C.: Changes in the North Sea fish community: evidence of indirect effects of fishing?, ICES J. Mar. Sci., 62, 177-188, 2005.

Dee, D. P., Uppala, S. M., Simmons, A. J., Berrisford, P., Poli, P., Kobayashi, S., Andrae, U., Balmaseda, M. A., Balsamo, G., Bauer, P., Bechtold, P., Beljaars, A. C. M., van de Berg, L., Bidlot, J., Bormann, N., Delsol, C., Dragani, R., Fuentes, M., Geer, A. J., Haimberger, L., Healy, S. B., Hersbach, H., Hólm, E. V., Isaksen, L., Kållberg, P., Köhler, M., Matricardi, M., McNally, A. P., Monge-Sanz, B. M., Morcrette, J.-J., Park, B.-K., Peubey, C., de Rosnay, P., Tavolato, C., Thépaut, J.-N., and Vitart, F.: The ERA-Interim reanalysis: configuration and performance of the 
data assimilation system, Q. J. Roy. Meteor. Soc., 137, 553-597, 2011.

Defra: Making the most of our evidence?: a strategy for Defra and its network, Department for Environment, Food and Rural Affairs, London, UK, 2014.

de Mora, L., Butenschön, M., and Allen, J. I.: How should sparse marine in situ measurements be compared to a continuous model: an example, Geosci. Model Dev., 6, 533-548, doi:10.5194/gmd6-533-2013, 2013.

de Mora, L., Butenschön, M., and Allen, J. I.: The assessment of a global marine ecosystem model on the basis of emergent properties and ecosystem function: a case study with ERSEM, Geosci. Model Dev., 9, 59-76, doi:10.5194/gmd-9-59-2016, 2016.

Devred, E., Sathyendranath, S., Stuart, V., and Platt, T.: A three component classification of phytoplankton absorption spectra: Application to ocean-color data, Remote Sens. Environ., 115, 2255-2266, 2011.

Donlon, C. J., Martin, M., Stark, J., Roberts-Jones, J., Fiedler, E., and Wimmer, W.: The operational sea surface temperature and sea ice analysis (OSTIA) system, Remote Sens. Environ., 116, 140-158, 2012.

Donnelly, C., Andersson, J. C., and Arheimer, B.: Using flow signatures and catchment similarities to evaluate the E-HYPE multibasin model across Europe, Hydrolog. Sci. J., 61, 255-273, 2015.

Dupont, N. and Aksnes, D. L.: Centennial changes in water clarity of the Baltic Sea and the North Sea, Estuar. Coast. Shelf S., 131, 282-289, 2013.

ECMWF: European Centre for Medium-Range Weather Forecasts (ECMWF) 40-year Re-Analysis (ERA-40) model data, NCAS British Atmospheric Data Centre, available at: http://catalogue. ceda.ac.uk/uuid/775634f7e339b5262067e28a5d7b679d (last access: July 2007), 2006a.

ECMWF: Assimilated Data from the European Centre for Medium-Range Weather Forecasts (ECMWF) operational analysis program, NCAS British Atmospheric Data Centre, available at: http://catalogue.ceda.ac.uk/uuidf6ce34fc/ c462480467660a36d9b10a71 (last access: January 2012), 2006b.

Edwards, K. P., Barciela, R., and Butenschön, M.: Validation of the NEMO-ERSEM operational ecosystem model for the North West European Continental Shelf, Ocean Sci., 8, 983-1000, doi:10.5194/os-8-983-2012, 2012.

Engel, A.: The role of transparent exopolymer particles (TEP) in the increase in apparent particle stickiness $(\alpha)$ during the decline of a diatom bloom, J. Plankton Res., 22, 485-497, 2000.

EU: Directive 2000/60/EC of the European Parliament and of the Council of 23 October 2000 establishing a framework for Community action in the field of water policy, European Parliament and Council of the European Union, Off. J. Eur. Communities, 327, 1-72, 2000.

EU: Directive 2008/56/EC of the European Parliament and of the Council of 17 June 2008 establishing a framework for community action in the field of marine environmental policy (Marine Strategy Framework Directive), European Parliament and Council of the European Union, Off. J. Eur. Union, 164, 19-40, 2008.

EU: Regulation (EU) No 1380/2013 of the European Parliament and of the Council of 11 December 2013 on the Common Fisheries Policy, amending council Regulations (EC) No 1954/2003 and (EC) No 1224/2009 and repealing Council regulations (EC)
No 2371/2002 and (EC) No 639/2004 and Council Decision 2004/585/EC, Off. J. Eur. Union, 354, 22-61, 2013.

Finkel, Z. V., Beardall, J., Flynn, K. J., Quigg, A., Rees, T. A. V., and Raven, J. A.: Phytoplankton in a changing world: cell size and elemental stoichiometry, J. Plankton Res., 32, 119-137, 2010.

Follows, M. J., Dutkiewicz, S., Grant, S., and Chisholm, S. W.: Emergent biogeography of microbial communities in a model ocean, Science, 315, 1843-1846, 2007.

Friedrichs, M. A., Dusenberry, J. A., Anderson, L. A., Armstrong, R. A., Chai, F., Christian, J. R., Doney, S. C., Dunne, J., Fujii, M., Hood, R., and McGillicuddy, D. J.: Assessment of skill and portability in regional marine biogeochemical models: Role of multiple planktonic groups, J. Geophys. Res.-Oceans, 112, C08001, doi:10.1029/2006JC003852, 2007.

Fulton, E. A. and Link, J. S.: Modeling Approaches for Marine Ecosystem-based Management, in: The Sea, Vol. 16: Marine Ecosystem-Based Management, edited by: Fogarty, M. J. and McCarthy, J. J., Harvard University Press, 2014.

Fulton, E. A., Link, J. S., Kaplan, I. C., Savina-Rolland, M., Johnson, P., Ainsworth, C., Horne, P., Gorton, R., Gamble, R. J., Smith, A. D., and Smith, D. C.: Lessons in modelling and management of marine ecosystems: the Atlantis experience, Fish Fish., 12, 171-188, 2007.

Garcia, H. E., Locarnini, R. A., Boyer, T. P., Antonov, J. I., Zweng, M. M., Baranova, O. K., and Johnson, D. R.: World Ocean Atlas 2009, Vol. 4: Nutrients (phosphate, nitrate, silicate), edited by: Levitus, S., NOAA Atlas NESDIS 71, US Government Printing Office, Washington, D.C., 398 pp., 2010.

Gårdmark, A., Lindegren, M., Neuenfeldt, S., Blenckner, T., Heikinheimo, O., Müller-Karulis, B., Niiranen, S., Tomczak, M. T., Aro, E., Wikström, A., and Möllmann, C.: Biological ensemble modeling to evaluate potential futures of living marine resources, Ecol. Appl., 23, 742-754, 2013.

Garmendia, M., Borja, A., Franco, J., and Revilla, M.: Phytoplankton composition indicators for the assessment of eutrophication in marine waters: Present state and challenges within the European directives, Mar. Pollut. Bull., 66, 7-16, 2013.

Gehlen, M., Barciela, R., Bertino, L., Brasseur, P., Butenschön, M., Chai, F., Crise, A., Drillet, Y., Ford, D., Lavoie, D., and Lehodey, P.: Building the capacity for forecasting marine biogeochemistry and ecosystems: recent advances and future developments, Journal of Operational Oceanography, 8, s168-s187, 2015.

Geider, R. J., MacIntyre, H. L., and Kana, T. M.: Dynamic model of phytoplankton growth and acclimation: responses of the balanced growth rate and the chlorophyll $a$ : carbon ratio to light, nutrient-limitation and temperature, Mar. Ecol.-Prog. Ser., 148, 187-200, 1997.

Gohin, F., Druon, J. N., and Lampert, L.: A five channel chlorophyll concentration algorithm applied to SeaWiFS data processed by SeaDAS in coastal waters, Int. J. Remote S., 23, 1639-1661, 2002.

Gohin, F., Loyer, S., Lunven, M., Labry, C., Froidefond, J. M., Delmas, D., Huret, M., and Herbland, A.: Satellite-derived parameters for biological modelling in coastal waters: Illustration over the eastern continental shelf of the Bay of Biscay, Remote Sens. Environ., 95, 29-46, 2005.

Gohin, F., Saulquin, B., Oger-Jeanneret, H., Lozac'h, L., Lampert, L., Lefebvre, A., Riou, P., and Bruchon, F.: Towards a better assessment of the ecological status of coastal waters using 
satellite-derived chlorophyll-a concentrations, Remote Sens. Environ., 112, 3329-3340, 2008.

Greenwood, N., Parker, E. R., Fernand, L., Sivyer, D. B., Weston, K., Painting, S. J., Kröger, S., Forster, R. M., Lees, H. E., Mills, D. K., and Laane, R. W. P. M.: Detection of low bottom water oxygen concentrations in the North Sea; implications for monitoring and assessment of ecosystem health, Biogeosciences, 7, 1357-1373, doi:10.5194/bg-7-1357-2010, 2010.

Gregg, W. W. and Casey, N. W.: Modeling coccolithophores in the global oceans, Deep-Sea Res. Pt II, 54, 447-477, 2007.

Hirata, T., Aiken, J., Hardman-Mountford, N., Smyth, T. J., and Barlow, R. G.: An absorption model to determine phytoplankton size classes from satellite ocean colour, Remote Sens. Environ., 112, 3153-3159, 2008.

Hirata, T., Hardman-Mountford, N. J., Brewin, R. J. W., Aiken, J., Barlow, R., Suzuki, K., Isada, T., Howell, E., Hashioka, T., Noguchi-Aita, M., and Yamanaka, Y.: Synoptic relationships between surface Chlorophyll-a and diagnostic pigments specific to phytoplankton functional types, Biogeosciences, 8, 311-327, doi:10.5194/bg-8-311-2011, 2011.

Hirata, T., Saux-Picart, S., Hashioka, T., Aita-Noguchi, M., Sumata, H., Shigemitsu, M., Allen, J. I., and Yamanaka, Y.: A comparison between phytoplankton community structures derived from a global 3D ecosystem model and satellite observation, J. Marine Syst., 109, 129-137, 2013.

Holt, J. T. and James, I. D.: An s coordinate density evolving model of the northwest European continental shelf: 1. Model description and density structure, J. Geophys. Res.-Oceans, 106, 1401514034, 2001.

Holt, J. T., Allen, J. I., Proctor, R., and Gilbert, F.: Error quantification of a high-resolution coupled hydrodynamic-ecosystem coastal-ocean model: Part 1. Model overview and assessment of the hydrodynamics, J. Marine Syst., 57, 167-188, 2005.

Holt, J., Allen, J. I., Anderson, T. R., Brewin, R., Butenschön, M., Harle, J., Huse, G., Lehodey, P., Lindemann, C., Memery, L., and Salihoglu, B.: Challenges in integrative approaches to modelling the marine ecosystems of the North Atlantic: Physics to fish and coasts to ocean, Prog. Oceanogr., 129, 285-313, 2014.

Hyder, K., Rossberg, A. G., Allen, J. I., Austen, M. C., Barciela, R. M., Bannister, H. J., Blackwell, P. G., Blanchard, J. L., Burrows, M. T., Defriez, E., and Dorrington, T.: Making modelling count-increasing the contribution of shelf-seas community and ecosystem models to policy development and management, Mar. Policy, 61, 291-302, 2015.

Jennings, S. and Collingridge, K.: Predicting consumer biomass, size-structure, production, catch potential, responses to fishing and associated uncertainties in the world's marine ecosystems, PloS one, 10, e0133794, doi:10.1371/journal.pone.0133794, 2015.

Jennings, S., Greenstreet, S., Hill, L., Piet, G., Pinnegar, J., and Warr, K. J.: Long-term trends in the trophic structure of the North Sea fish community: evidence from stable-isotope analysis, sizespectra and community metrics, Mar. Biol., 141, 1085-1097, 2002.

Jupp, T. E., Lowe, R., Coelho, C. A., and Stephenson, D. B.: On the visualization, verification and recalibration of ternary probabilistic forecasts, Philos. T. R. Soc. A, 370, 1100-1120, 2012.

Kurekin, A. A., Miller, P. I., and van der Woerd, H. J.: Satellite discrimination of Karenia mikimotoi and Phaeocystis harmful al- gal blooms in European coastal waters: Merged classification of ocean colour data, Harmful Algae, 31, 163-176, 2014.

Kwiatkowski, L., Yool, A., Allen, J. I., Anderson, T. R., Barciela, R., Buitenhuis, E. T., Butenschön, M., Enright, C., Halloran, P. R., Le Quéré, C., de Mora, L., Racault, M.-F., Sinha, B., Totterdell, I. J., and Cox, P. M.: iMarNet: an ocean biogeochemistry model intercomparison project within a common physical ocean modelling framework, Biogeosciences, 11, 7291-7304, doi:10.5194/bg-11-7291-2014, 2014.

Lenhart, H. J., Mills, D. K., Baretta-Bekker, H., van Leeuwen, S. M., van der Molen, J., Baretta, J. W., Blaas, M., Desmit, X., Kühn, W., Lacroix, G., Los, H. J., Ménesguen, A., Neves, R., Proctor, R., Ruardij, P., Skogen, M. D., Vanhoutte-Grunier, A., Villars, M. T., and Wakelin, S. L.: Predicting the consequences of nutrient reduction on the eutrophication status of the North Sea, J. Marine Syst., 81, 148-170, 2010.

Le Quéré, C., Harrison, S. P., Prentice, I. C., Buitenhuis, E. T., Aumont, O., Bopp, L., Claustre, H., Cotrim Da Cunha, L., Geider, R., Giraud, X., and Klaas, C.: Ecosystem dynamics based on plankton functional types for global ocean biogeochemistry models, Global Change Biol., 11, 2016-2040, 2005.

Lewis, K. and Allen, J. I.: Validation of a hydrodynamic-ecosystem model simulation with time-series data collected in the western English Channel, J. Marine Syst., 77, 296-311, 2009.

Lewis, K., Allen, J. I., Richardson, A. J., and Holt, J. T.: Error quantification of a high resolution coupled hydrodynamic-ecosystem coastal-ocean model: Part 3, validation with Continuous Plankton Recorder data, J. Marine Syst., 63, 209-224, 2006.

Mackinson, S.: Combined analyses reveal environmentally driven changes in the North Sea ecosystem and raise questions regarding what makes an ecosystem model's performance credible?, Can. J. Fish. Aquat. Sci., 71, 31-46, 2014.

MacLachlan, C., Arribas, A., Peterson, D., Maidens, A., Fereday, D., Scaife, A. A., Gordon, M., Vellinga, M., Williams, A., Comer, R. E., Camp, J., and Xavier, P.: Global Seasonal Forecast System 5 (GloSea5): a high resolution seasonal forecast system, Q. J. Roy. Meteor. Soc., 141, 1072-1084, 2014.

Madec, G.: NEMO ocean engine, Note du Pole de modélisation, Insititut Pierre-Simon Laplace (IPSL), France, No. 27, 2008.

Mogensen, K., Balmaseda, M., and Weaver, A.: The NEMOVAR ocean data assimilation system as implemented in the ECMWF ocean analysis for System4, ECMWF Technical Memorandum 668, 59 pp., 2012.

Nair, A., Sathyendranath, S., Platt, T., Morales, J., Stuart, V., Forget, M.-H., Devred, E., and Bouman, H.: Remote sensing of phytoplankton functional types, Remote Sens. Environ., 112, 33663375, 2008.

Núñez-Riboni, I. and Akimova, A.: Monthly maps of optimally interpolated in situ hydrography in the North Sea from 1948 to 2013, J. Marine Syst., 151, 15-34, 2015.

O'Dea, E., Furner, R., Wakelin, S., Siddorn, J., While, J., Sykes, P., King, R., Holt, J., and Hewitt, H.: The CO5 configuration of the $7 \mathrm{~km}$ Atlantic Margin Model: Large scale biases and sensitivity to forcing, physics options and vertical resolution, Geosci. Model Dev. Discuss., doi:10.5194/gmd-2017-15, in review, 2017.

O’Dea, E. J., Arnold, A. K., Edwards, K. P., Furner, R., Hyder, P., Martin, M. J., Siddorn, J. R., Storkey, D., While, J., Holt, J. T., and Liu, H.: An operational ocean forecast system incorporating NEMO and SST data assimilation for the tidally driven European 
North-West shelf, Journal of Operational Oceanography, 5, 3-17, 2012.

Peloquin, J., Swan, C., Gruber, N., Vogt, M., Claustre, H., Ras, J., Uitz, J., Barlow, R., Behrenfeld, M., Bidigare, R., Dierssen, H., Ditullio, G., Fernandez, E., Gallienne, C., Gibb, S., Goericke, R., Harding, L., Head, E., Holligan, P., Hooker, S., Karl, D., Landry, M., Letelier, R., Llewellyn, C. A., Lomas, M., Lucas, M., Mannino, A., Marty, J.-C., Mitchell, B. G., Muller-Karger, F., Nelson, N., O’Brien, C., Prezelin, B., Repeta, D., Jr. Smith, W. O., Smythe-Wright, D., Stumpf, R., Subramaniam, A., Suzuki, K., Trees, C., Vernet, M., Wasmund, N., and Wright, S.: The MAREDAT global database of high performance liquid chromatography marine pigment measurements, Earth Syst. Sci. Data, 5, 109123, doi:10.5194/essd-5-109-2013, 2013.

Peperzak, L., Colijn, F., Gieskes, W. W. C., and Peeters, J. C. H.: Development of the diatom-Phaeocystis spring bloom in the Dutch coastal zone of the North Sea: the silicon depletion versus the daily irradiance threshold hypothesis, J. Plankton Res., 20, 517-537, 1998.

Petersen, W., Wehde, H., Krasemann, H., Colijn, F., and Schroeder, F.: FerryBox and MERIS - Assessment of coastal and shelf sea ecosystems by combining in situ and remotely sensed data, Estuar. Coast. Shelf. S., 77, 296-307, 2008.

Piroddi, C., Teixeira, H., Lynam, C. P., Smith, C., Alvarez, M. C., Mazik, K., Andonegi, E., Churilova, T., Tedesco, L., Chifflet, M., and Chust, G.: Using ecological models to assess ecosystem status in support of the European Marine Strategy Framework Directive, Ecol. Indic., 58, 175-191, 2015.

Plagányi, É. E., Punt, A. E., Hillary, R., Morello, E. B., Thébaud, O., Hutton, T., Pillans, R. D., Thorson, J. T., Fulton, E. A., Smith, A. D., and Smith, F.: Multispecies fisheries management and conservation: tactical applications using models of intermediate complexity, Fish Fish., 15, 1-22, 2014.

Richardson, A. J., Walne, A. W., John, A. W. G., Jonas, T. D., Lindley, J. A., Sims, D. W., Stevens, D., and Witt, M.: Using continuous plankton recorder data, Prog. Oceanogr., 68, 27-74, 2006.

Rombouts, I., Beaugrand, G., Fizzala, X., Gaill, F., Greenstreet, S. P. R., Lamare, S., Le Loc'h, F., McQuatters-Gollop, A., Mialet, B., Niquil, N., and Percelay, J.: Food web indicators under the Marine Strategy Framework Directive: From complexity to simplicity?, Ecol. Indic., 29, 246-254, 2013.

Roselli, L. and Basset, A.: Decoding size distribution patterns in marine and transitional water phytoplankton: from community to species level, PloS one, 10, e0127193, doi:10.1371/journal.pone.0127193, 2015.

Ruardij, P. and van Raaphorst, W.: Benthic nutrient regeneration in the ERSEM-BFM ecosystem model of the North Sea, Neth. J. Sea Res., 33, 453-483, 1995.

Ruardij, P., van Haren, H., and Ridderinkhof, H.: The impact of thermal stratification on phytoplankton and nutrient dynamics in shelf seas, J. Sea Res., 38, 311-331, 1997.

Ruardij, P., Veldhuis, M. J. W., and Brussaard, C. P. D.: Modeling the bloom dynamics of the polymorphic phytoplankter Phaeocystis globosa: impact of grazers and viruses, Harmful Algae, 4, 941-963, 2005.

Ryther, J. H.: Photosynthesis and fish production in the sea. The production of organic matter and its conversion to higher forms of life vary throughout the world ocean, Science, 166, 72-76, 1969.
Schlüter, L., Henriksen, P., Nielsen, T. G., and Jakobsen, H. H.: Phytoplankton composition and biomass across the southern Indian Ocean, Deep-Sea Res. Pt I, 58, 546-556, 2011.

Schlüter, L., Møhlenberg, F., and Kaas, H.: Temporal and spatial variability of phytoplankton monitored by a combination of monitoring buoys, pigment analysis and fast screening microscopy in the Fehmarn Belt Estuary, Environ. Monit. Assess., 186, 51675184, 2014.

Shephard, S., Greenstreet, S. P., Piet, G. J., Rindorf, A., and DickeyCollas, M.: Surveillance indicators and their use in implementation of the Marine Strategy Framework Directive, ICES J. Mar. Sci., 72, 2269-2277, doi:10.1093/icesjms/fsv131, 2015.

Sherrard, N. J., Nimmo, M., and Llewellyn, C. A.: Combining HPLC pigment markers and ecological similarity indices to assess phytoplankton community structure: an environmental tool for eutrophication?, Sci. Total Environ., 361, 97-110, 2006.

Siddorn, J. R. and Furner, R.: An analytical stretching function that combines the best attributes of geopotential and terrain-following vertical coordinates, Ocean Model., 66, 1-13, 2013.

Sinha, B., Buitenhuis, E. T., Le Quéré, C., and Anderson, T. R.: Comparison of the emergent behavior of a complex ecosystem model in two ocean general circulation models, Prog. Oceanogr., 84, 204-224, 2010.

Skogen, M. D., Eilola, K., Hansen, J. L. S., Meier, H. E. M., Molchanov, M. S., and Ryabchenko, V. A.: Eutrophication status of the North Sea, Skagerrak, Kattegat and the Baltic Sea in present and future climates: A model study, J. Marine Syst., 132, 174-184, 2014.

Smaal, A. C., Schellekens, T., van Stralen, M. R., and Kromkamp, J. C.: Decrease of the carrying capacity of the Oosterschelde estuary (SW Delta, NL) for bivalve filter feeders due to overgrazing?, Aquaculture, 404, 28-34, 2013.

Stewart, I. J. and Martell, S. J.: Reconciling stock assessment paradigms to better inform fisheries management, ICES J. Mar Sci., 72, 2187-2196, doi:10.1093/icesjms/fsv061, 2015.

Stips, A., Bolding, K., Pohlmann, T., and Burchard, H.: Simulating the temporal and spatial dynamics of the North Sea using the new model GETM (General Estuarine Transport Model), Ocean Dynam., 54, 266-283, 2004.

Storkey, D., Blockley, E. W., Furner, R., Guiavarc'h, C., Lea, D., Martin, M. J., Barciela, R. M., Hines, A., Hyder, P. and Siddorn, J. R.: Forecasting the ocean state using NEMO: The new FOAM system, Journal of Operational Oceanography, 3, 3-15, 2010.

Sutherland, W. J., Armstrong-Brown, S., Armsworth, P. R., Tom, B., Brickland, J., Campbell, C. D., Chamberlain, D. E., Cooke, A. I., Dulvy, N. K., Dusic, N. R., and Fitton, M.: The identification of 100 ecological questions of high policy relevance in the UK, J. Appl. Ecol., 43, 617-627, 2006.

Sykes, P. A. and Barciela, R. M.: Assessment and development of a sediment model within an operational system, J. Geophys. Res.Oceans, 117, C04036, doi10.1029/2011JC007420, 2012.

Taylor, K. E.: Summarizing multiple aspects of model performance in a single diagram, J. Geophys. Res.-Atmos., 106, 7183-7192, 2001.

Tebaldi, C. and Knutti, R.: The use of the multi-model ensemble in probabilistic climate projections, Philos. T. R. Soc. A, 365, 2053-2075, 2007.

Thorpe, R. B., Le Quesne, W. J., Luxford, F., Collie, J. S., and Jennings, S.: Evaluation and management implications of uncer- 
tainty in a multispecies size-structured model of population and community responses to fishing, Methods Ecol. Evol., 6, 49-58, 2015.

Thyssen, M., Alvain, S., Lefèbvre, A., Dessailly, D., Rijkeboer, M., Guiselin, N., Creach, V., and Artigas, L.-F.: High-resolution analysis of a North Sea phytoplankton community structure based on in situ flow cytometry observations and potential implication for remote sensing, Biogeosciences, 12, 4051-4066, doi:10.5194/bg-12-4051-2015, 2015.

Uitz, J., Claustre, H., Morel, A., and Hooker, S. B.: Vertical distribution of phytoplankton communities in open ocean: An assessment based on surface chlorophyll, J. Geophys. Res.-Oceans, 111, C08005, doi:10.1029/2005JC003207, 2006.

Uitz, J., Huot, Y., Bruyant, F., Babin, M., and Claustre, H.: Relating phytoplankton photophysiological properties to community structure on large scales, Limnol. Oceanogr., 53, 614-630, 2008.

Van der Molen, J., Aldridge, J. N., Coughlan, C., Parker, E. R., Stephens, D., and Ruardij, P.: Modelling marine ecosystem response to climate change and trawling in the North Sea, Biogeochemistry, 113, 213-236, 2013.

Van der Molen, J., Smith, H. C. M., Lepper, P., Limpenny, S., and Rees, J.: Predicting the large-scale consequences of offshore wind turbine array development on a North Sea ecosystem, Cont. Shelf Res., 85, 60-72, 2014.

van der Molen, J., van Beek, J., Augustine, S., Vansteenbrugge, L., van Walraven, L., Langenberg, V., van der Veer, H. W., Hostens, K., Pitois, S., and Robbens, J.: Modelling survival and connectivity of Mnemiopsis leidyi in the south-western North Sea and Scheldt estuaries, Ocean Sci., 11, 405-424, doi:10.5194/os-11405-2015, 2015.

van der Molen, J., Ruardij, P., and Greenwood, N.: Potential environmental impact of tidal energy extraction in the Pentland Firth at large spatial scales: results of a biogeochemical model, Biogeosciences, 13, 2593-2609, doi:10.5194/bg-13-2593-2016, 2016.

Van der Molen, J., Ruardij, P., and Greenwood, N.: A 3D SPM model for biogeochemical modelling, with application to the northwest European continental shelf, J. Sea Res., in press, 2017.

Van Leeuwen, S., Tett, P., Mills, D., and van der Molen, J.: Stratified and non-stratified areas in the North Sea: Long-term variability and biological and policy implications, J. Geophys. Res.-Oceans, 120, 4670-4686, 2015.

Van Leeuwen, S. M., van der Molen, J., Ruardij, P., Fernand, L., and Jickells, T.: Modelling the contribution of deep chlorophyll maxima to annual primary production in the North Sea, Biogeochemistry, 113, 137-152, 2013.
Veldhuis, M. J. W. and Admiraal, W.: Influence of phosphate depletion on the growth and colony formation of Phaeocystis pouchetii, Mar. Biol., 95, 47-54, 1987.

Vichi, M., Oddo, P., Zavatarelli, M., Coluccelli, A., Coppini, G., Celio, M., Fonda Umani, S., and Pinardi, N.: Calibration and validation of a one-dimensional complex marine biogeochemical flux model in different areas of the northern Adriatic shelf, Ann. Geophys., 21, 413-436, doi:10.5194/angeo-21-413-2003, 2003.

Vichi, M., Ruardij, P., and Baretta, J. W.: Link or sink: a modelling interpretation of the open Baltic biogeochemistry, Biogeosciences, 1, 79-100, doi:10.5194/bg-1-79-2004, 2004.

Vichi, M., Pinardi, N., and Masina, S.: A generalized model of pelagic biogeochemistry for the global ocean ecosystem. Part I: Theory, J. Marine Syst., 64, 89-109, 2007.

Wakelin, S. L., Artioli, Y., Butenschön, M., Allen, J. I., and Holt, J. T.: Modelling the combined impacts of climate change and direct anthropogenic drivers on the ecosystem of the northwest European continental shelf, J. Marine Syst., 152, 51-63, 2015a.

Wakelin, S., While, J., King, R., O'Dea, E., Holt, J., Furner, R., Siddorn, J., Martin, M., McEwan, R., Blockley, E., and Tinker, J.: Quality Information Document: North West European Shelf Reanalysis - NORTHWESTSHELF_REANALYSIS_PHYS_004_009 and NORTHWESTSHELF_REANALYSIS_BIO_004_011, EU Copernicus Marine Environment Monitoring Service, available at: http://marine.copernicus.eu/documents/QUID/ CMEMS-NWS-QUID-004-009-011.pdf (last access: 2 March 2017), 2015 b.

Ward, B. A., Schartau, M., Oschlies, A., Martin, A. P., Follows, M. J., and Anderson, T. R.: When is a biogeochemical model too complex? Objective model reduction and selection for North Atlantic time-series sites, Prog. Oceanogr., 116, 49-65, 2013.

Waters, J., Lea, D. J., Martin, M. J., Mirouze, I., Weaver, A., and While, J.: Implementing a variational data assimilation system in an operational 1/4 degree global ocean model, Q. J. Roy. Meteor. Soc., 141, 333-349, 2015.

Wollschläger, J., Wiltshire, K. H., Petersen, W., and Metfies, K.: Analysis of phytoplankton distribution and community structure in the German Bight with respect to the different size classes, J. Sea Res., 99, 83-96, 2015.

Xiao, Y. and Friedrichs, M. A. M.: Using biogeochemical data assimilation to assess the relative skill of multiple ecosystem models in the Mid-Atlantic Bight: effects of increasing the complexity of the planktonic food web, Biogeosciences, 11, 3015-3030, doi:10.5194/bg-11-3015-2014, 2014. 